
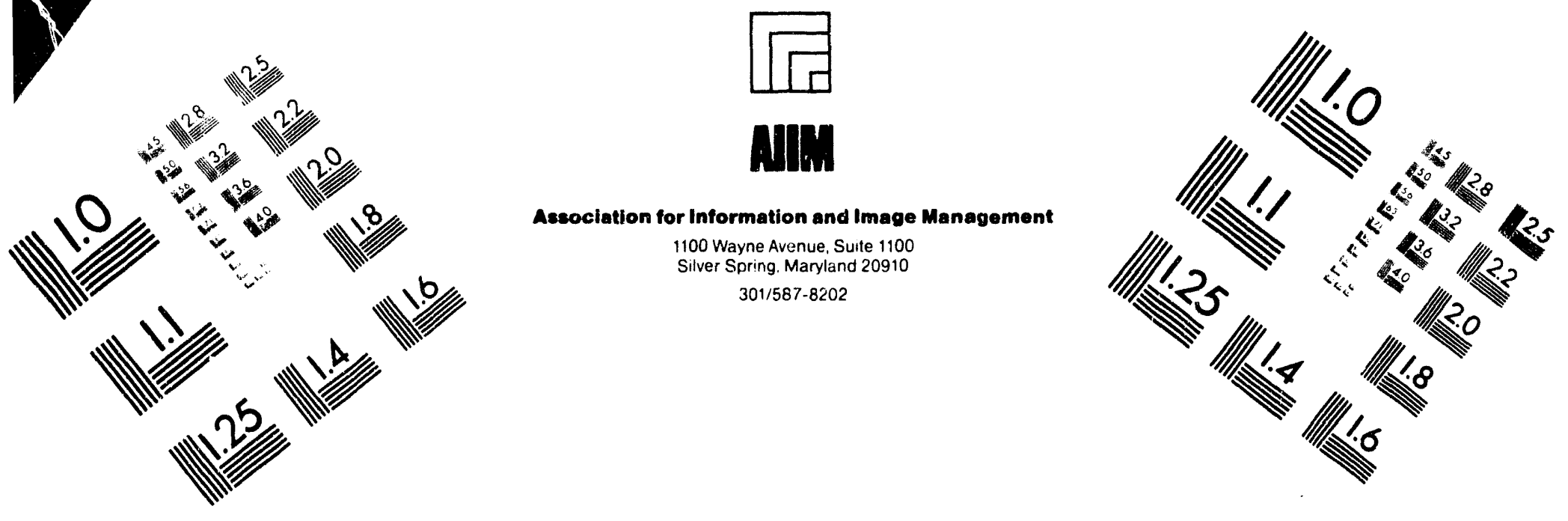

Centimeter

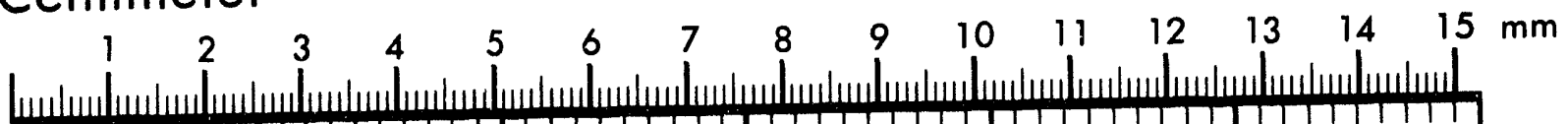

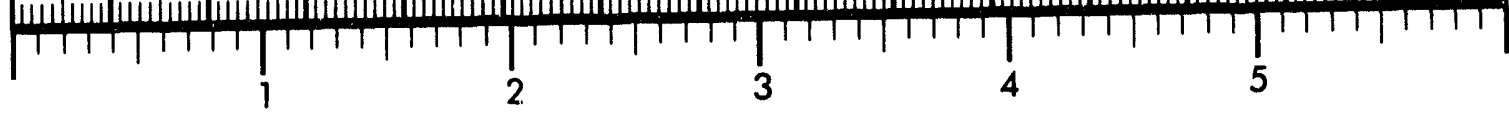
Inches
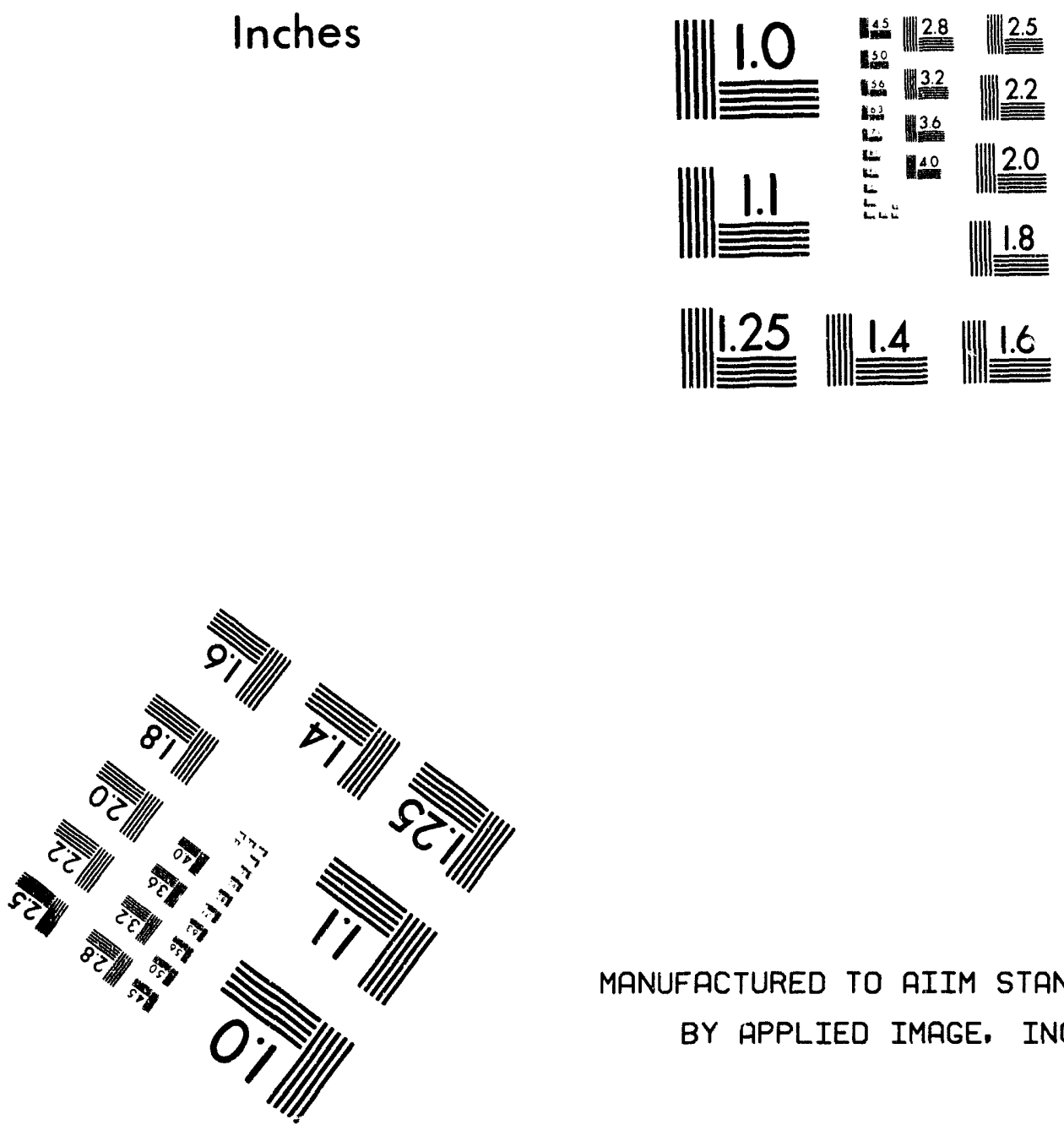

MANUFACTURED TO AIIM STANDARDS

BY APPLIED IMAGE, INC.

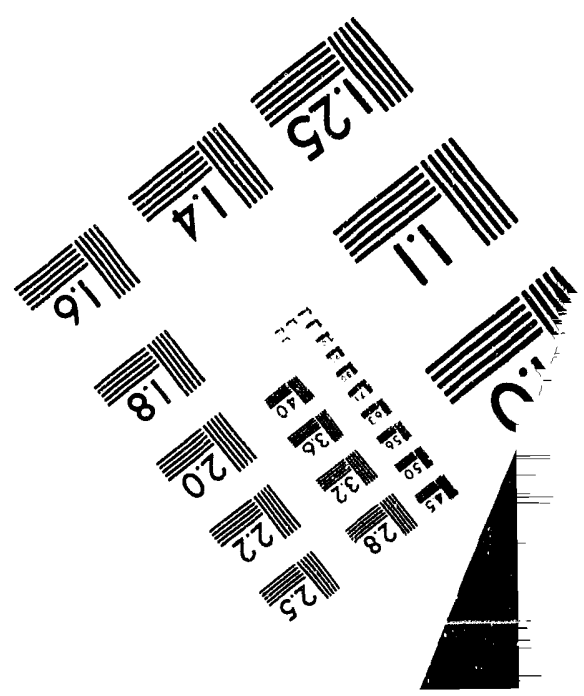



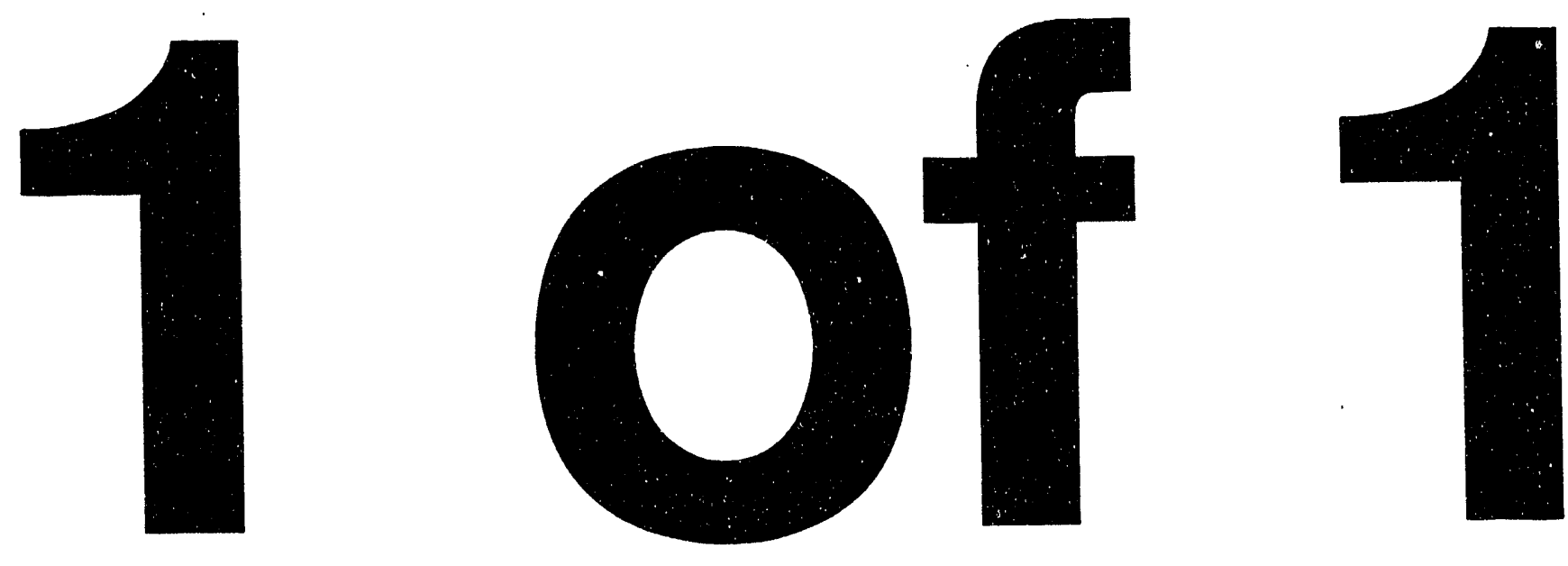
Interim Report

\title{
PILOT-SCALE FIELD TESTS FOR THE METHANOTROPHIC TECHNOLOGY COMETABOLIC BIOREACTOR DEMONSTRATION AT THE OAK RIDGE K-25 SITE
}

\author{
T. L. Donaldson \\ A. J. Lucero \\ H. L. Jennings
}

Chemical Technology Division

\author{
S. E. Herbes
}

Environmental Sciences Division

Oak Ridge National Laboratory

Oak Ridge, Tennessee 37831

June 1993

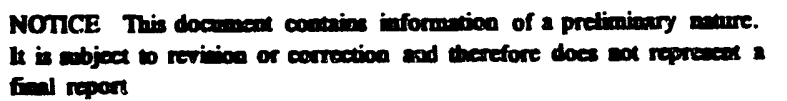

find repon

Prepared by the

OAK RIDGE NATIONAL LABORATORY

Oak Ridge, Tennessee 37831

managed by

MARTIN MARIETTA ENERGY SYSTEMS, INC.

for the

U. S. DEPARTMENT OF ENERGY

under contract DE-AC05-84OR21400

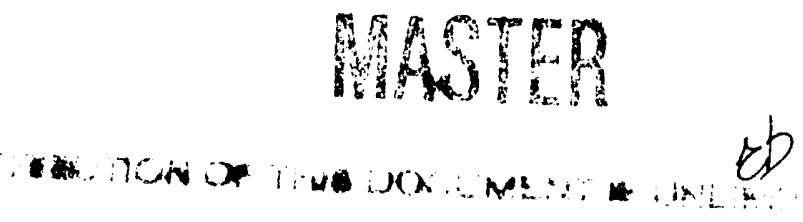




\section{CONTENTS}

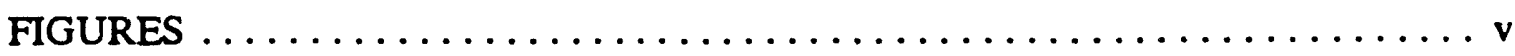

TABLES $\ldots \ldots \ldots \ldots \ldots \ldots \ldots \ldots \ldots \ldots \ldots \ldots \ldots \ldots \ldots \ldots \ldots$

EXECUTTVE SUMMARY $\ldots \ldots \ldots \ldots \ldots \ldots \ldots \ldots \ldots \ldots \ldots \ldots \ldots \ldots$

1. INTRODUCTION $\ldots \ldots \ldots \ldots \ldots \ldots \ldots \ldots \ldots \ldots \ldots \ldots \ldots \ldots \ldots$

1.1 BACKGROUND $\ldots \ldots \ldots \ldots \ldots \ldots \ldots \ldots \ldots \ldots \ldots \ldots \ldots \ldots$

1.2 BIODEGRADATION CHEMISTRY $\ldots \ldots \ldots \ldots \ldots \ldots \ldots \ldots \ldots \ldots \ldots$

1.3 SCOPE OF PILOT-SCALE FIELD TESTS $\ldots \ldots \ldots \ldots \ldots \ldots \ldots \ldots$

1.4 PROJECT OVERVIEW AND CHRONOLOGY $\ldots \ldots \ldots \ldots \ldots \ldots \ldots$

2. PROCESS EQUIPMENT DESCRIPTION $\ldots \ldots \ldots \ldots \ldots \ldots \ldots \ldots \ldots \ldots$

2.1 BIOREACTOR SKID UNIT $\ldots \ldots \ldots \ldots \ldots \ldots \ldots \ldots \ldots \ldots \ldots$

2.2 PRETREATMENT SYSTEMS $\ldots \ldots \ldots \ldots \ldots \ldots \ldots \ldots \ldots \ldots \ldots$

2.3 FIELD INSTALLATION $\ldots \ldots \ldots \ldots \ldots \ldots \ldots \ldots \ldots \ldots \ldots \ldots$

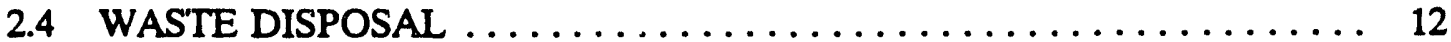

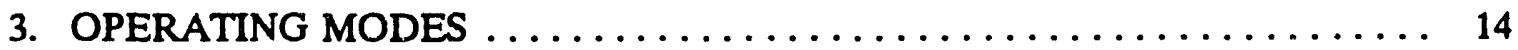

3.1 STEAM STRIPPING PRETREATMENT $\ldots \ldots \ldots \ldots \ldots \ldots \ldots \ldots \ldots$

3.2 AIR OXIDATION PRETREATMENT $\ldots \ldots \ldots \ldots \ldots \ldots \ldots \ldots \ldots \ldots$

3.3 NO PRETREATMENT $\ldots \ldots \ldots \ldots \ldots \ldots \ldots \ldots \ldots \ldots \ldots \ldots \ldots$

4. PROCESS MONITORING AND SAMPLING $\ldots \ldots \ldots \ldots \ldots \ldots \ldots \ldots \ldots$

4.1 PROCESS CONTROL AND PERFORMANCE $\ldots \ldots \ldots \ldots \ldots \ldots \ldots \ldots$

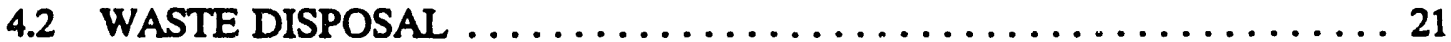

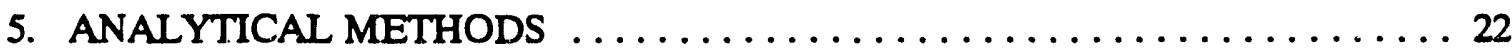

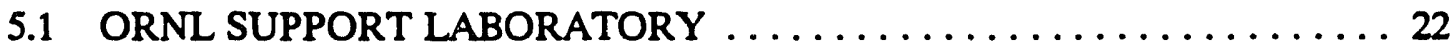

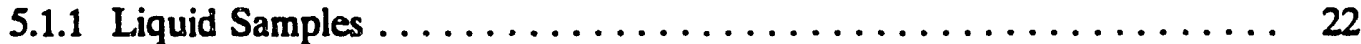

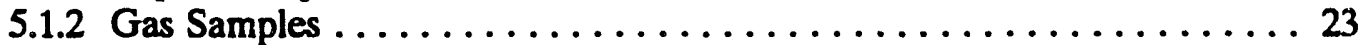

5.2 K-25 ANALYTICAL LABORATORY ................. 23

6. DATA MANAGEMENT AND ANALYSIS $\ldots \ldots \ldots \ldots \ldots \ldots \ldots \ldots \ldots$

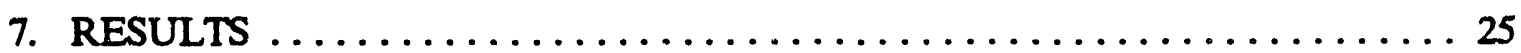

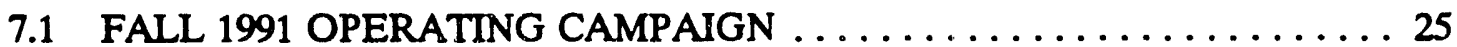

7.2 SPRING/SUMMER 1992 OPERATING CAMPAIGN ........... 27 


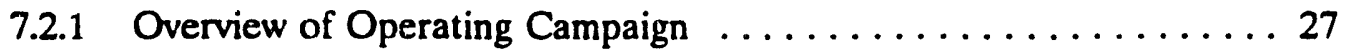

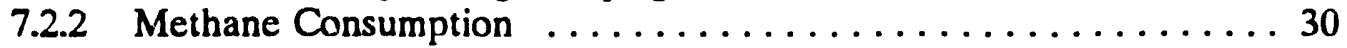

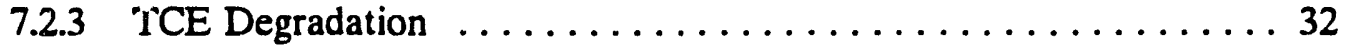

7.2 .4 Degradation of Other Organics .................. 35

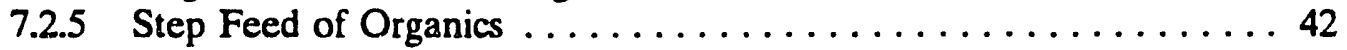

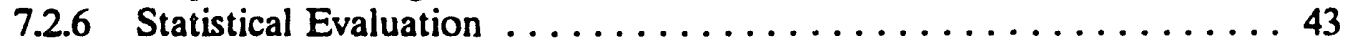

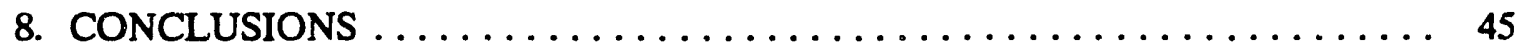

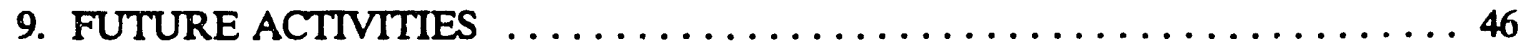

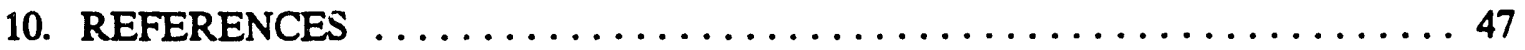

Appendix A .............................. 49 


\section{FIGURES}

1. Process flow sheet for the cometabolic bioreactor system with air oxidation and steam stripping pretreatment options $\ldots \ldots \ldots \ldots \ldots \ldots \ldots$

2. Koch packing (a) and liquid distributor (b) in the bioreactor columns ............................... 10

3. Equipment layout in the process trailer for the cometabolic bioreactor

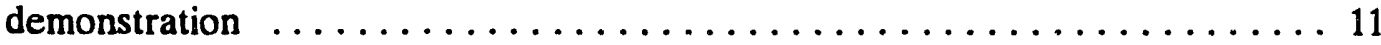

4. Site plot for the cometabolic bioreactor demonstration at the K-25

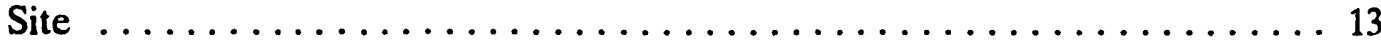

5. Operational mode 1: steam stripper pretreatment $\ldots \ldots \ldots \ldots \ldots \ldots \ldots$

6. Operational mode 2: air oxidation pretreatment with steam stripping

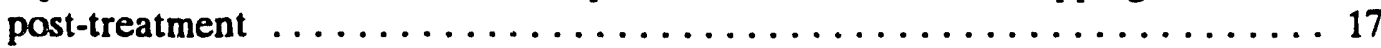

7. Operational mode 3: direct treatment of seep water with steam stripping post-treatment .............................. 19

8. Location of sampling points for process performance monitoring $\ldots \ldots \ldots 20$

9. Flow rates of (a) seep water to process; (b) methane/air to Column A; and (c) methane/air to Column B

10. Mass flow rates of methane into and out of process $\ldots \ldots \ldots \ldots \ldots \ldots$

11. Mass flow rates of trichloroethylene (TCE) into and out of process $\ldots \ldots \ldots 33$

12. Degradation of trichloroethylene (TCE) in both bioreactors by steady-state material balance $\ldots \ldots \ldots \ldots \ldots \ldots \ldots \ldots \ldots \ldots \ldots \ldots \ldots . \ldots \ldots$

13. Mass flow rates of 1,1-dichloroethane (1,1-DCA) into and out of

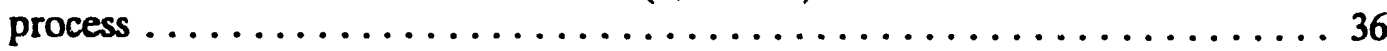

14. Degradation of 1,1-dichloroethane (1,1-DCA) in both bioreactors calculated from steady-state material balance

15. Mass flow rates of 1,1,1-trichloroethane (1,1,1-TCA) into and out of process

16. Degradation of 1,1,1-trichloroethane (1,1,1-TCA.) in both bioreactors calculated from steady-state material balance

17. Mass flow rates of perchloroethylene (PCE) ito and out of process $\ldots \ldots \ldots 40$

18. Degradation of perchloroethylene (PCE) in both bioreactors calculated from steady-state material balance 


\section{TABLES}

1. Contaminants detected in Storm Drain SD-180-04 (new sampling point designation: SU-31) at the K-25 Facility, April 1990. All concentrations reported in units of $\mathrm{mg} / \mathrm{L}(\mathrm{ppm})$ except alpha and gamma activity $(\mathrm{pCi} / \mathrm{L})$. Underlining indicates chlorinated volatiles and aromatic compounds that may be degraded to some extent in the bioreactor $\ldots \ldots \ldots \ldots \ldots \ldots \ldots$

2. Major events during cometabolic bioreactor demonstration $\ldots \ldots \ldots \ldots \ldots \ldots$

3. Waste acceptance criteria for the Central Neutralization Facility $\ldots \ldots \ldots 15$

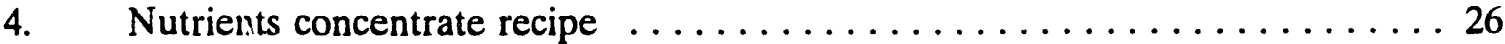

5. Statistical evaluation of the average differences between the apparent percen: degradation of TCE; 1,1,1-TCA; and 1,1-DCA relative to the apparent percent degradation of PCE . . . . . . . . . . . . . 44 


\section{EXECUTTVE SUMMARY}

The Oak Ridge National Laboratory (ORNL) is conducting a demonstration of cometabolic technology for bioremediation of groundwater contaminated with trichloroethylene (TCE) and other chlorinated and aromatic solvents. The technology demonstration is located at a seep from the K-1070-C/D Classified Burial Ground at the Oak Ridge K-25 Site. Funding for this demonstration is provided by the U.S. Department of Energy (DOE), Environmental Restoration/Waste Management Program, Office ú Technology Development.

The technology demonstration is designed to evaluate the performance of two different types of cometabolic processes. In both cases, the TCE is cometabolized in the sense that utilization of a different primary substrate is necessary to obtain the simultaneous (co)metabolism of TCE. Trichloroethylene alone is unable to support growth and maintenance of the microorganisms. Methanotrophic (methane-utilizing) technology is being demonstrated first; toluene-utilizing microorganisms will be demonstrated later, funding permitting. The demonstration is based on scaleup of laboratory and bench-scale prototype equipment that was used to establish the technical feasibility of the processes.

Cometabolic biotreatment of chlorinated organics in groundwater offers several potential advantages over air stripping technologies now used for treatment of groundwater. The organics are destroyed biologically, and no large off-gas streams are created that require further treatment by activated carbon and/or incineration for disposal. The cometabolic technologies are expected to generate very small quantities of biosludge and off-gas (no air permit was required for this demonstration). Equipment requirements are simple, and costs for cometabolic biotreatment of groundwater are projected to be comparable to costs for treatment of municipal and low-strength industrial wastewaters. Successful demonstration of 
this technology at the pilot scale will help to validate performance expectations and to encourage further application to DOE's environmental remediation and waste management problems.

This interim report is a summary of the start-up and early operation of the methanotrophic bioreactor system to treat the seep water at the demonstration site. The initial objectives were to

(1) demonstrate stable operation of the bioreactors and associated equipment, including the pretreatment and effluent polishing steps; and

(2) evaluate the biodegradation of TCE and other organics in the seep water for the three operating modes - air oxidation pretreatment, steam stripping pretreatment, and no pretreatment.

A bioreactor skid system is on loan to ORNL from the Air Force Civil Engineering Support Agency (AFCESA). It has been modified and upgraded for the present application and is contained within a van-type trailer installed at the demonstration site. Start-up was achieved in late September 1991 to meet an award-fee milestone. After a brief operating period, in which difficulties were encountered with the steam supply for the steam stripper, winter operation was discontinued because of a lack of funding. Operation in the air oxidation pretreatment mode was initiated in March 1992 following receipt of funds.

The air oxidation mode has been operated successfully, and performance data have been obtained during start-up and for one relatively stable extended operating period of $\sim 2$ weeks. Equipment malfunctions and delays in waste disposal interfered with operation on several occasions and limited the amount of data obtained. Evidence for degradation of TCE and other volatile organic compounds (VOCs) was seen early in the June operating period and in late August, with apparently no sustained degradation in early August. (There was no 
operation in July because of waste disposal procedures.) Factors that may have contributed to the apparent lack of sustained degradation include frequent unsteady-state conditions and data variability, a $\mathrm{pH}$ excursion for several hours when the $\mathrm{pH}$ controller failed, and insufficient hydraulic residence time for treatment of low concentrations of VOCs.

Operation in the air oxidation pretreatment mode was discontinued on September 1 coincident with the need for waste disposal. The microbial culture will be sampled and tested for TCE-degrading activity in the laboratory. If the activity is low, the bioreactors will be reinoculated. The steam stripping pretreatment mode will be tested when operation resumes in September. 


\section{INTRODUCTION}

\subsection{BACKGROUND}

ORNL is conducting a demonstration of two cometabolic technologies for biotreatment of groundwater contaminated with TCE and other chlorinated and aromatic compounds. The demonstration is based on scaleup of laboratory and bench-scale prototype equipment that was used to establish the technical feasibility of the processes. The technology demonstration is located at a seep from the K-1070-C/D Classified Burial Ground at the Oak Ridge K-25 Site. Funding for this demonstration is provided by the U.S. DOE Environmental Restoration/Waste Management Program, Office of Technology Development.

The seep water contains TCE, perchloroethylene (PCE), benzene, toluene, chlorinated ethanes, and other VOCs at a total concentration of several parts per million (ppm) (see Table 1). This seep water is currently discharged through a National Pollution Discharge Elimination System (NPDES) permitted outfall. To maintain regulatory compliance, the treated water from the demonstration process is collected in a tanker trailer and transported to the Central Neutralization Facility (CNF), a licensed treatment facility at the K-25 Site.

Cometabolic biotreatment of chlorinated organics in groundwater offers several potential advantages over air stripping technologies now used for treatment of groundwater. The organics are destroyed biologically, and no large off-gas streams are created that require further treatment by activated carbon and/or incineration for disposal. The cometabolic technologies are expected to generate very small quantities of biosludge and off-gas. (No air permit was required for this demonstration.) Equipment requirements are simple, and costs for cometabolic biotreatment of groundwater are projected to be comparable to costs for treatment of municipal and low-strength industrial wastewaters. Successful demonstration of 
Table 1. Contaminants detected in Storm Drain SD-180-04 (new sampling point designation: SU-31) at the K-25 Facility, April 1990. All concentrations reported in units of $\mathrm{mg} / \mathrm{L}(\mathrm{ppm})$ except alpha and gamma activity $(\mathrm{pCi} / \mathrm{L})$. Underlining indicates chlorinated volatiles and aromatic compounds that may be degraded to some extent in the bioreactor.

\begin{tabular}{|c|c|c|c|c|}
\hline Chemical & $\begin{array}{l}\text { Number } \\
\text { detected }\end{array}$ & $\begin{array}{c}\text { Range of } \\
\text { detection } \\
\text { limits } \\
\end{array}$ & $\begin{array}{l}\text { Values above } \\
\text { detection } \\
\text { limits }\end{array}$ & $\begin{array}{l}\text { Average } \\
\text { value }\end{array}$ \\
\hline 1.d-Trichlorcethane & $4 / 4$ & 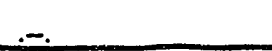 & $4.9-6.8$ & 5.9 \\
\hline 12.IJ-ahlaroethane & $2 / 4$ & $0.25-0.25$ & $0.025=0.033$ & 0.029 \\
\hline 1.1-Dichloroeshane & $4 / 4$ &.- & $0.98-1$ & 0.005 \\
\hline 1,1-Dichloroethene & $4 / 4$ & $\ldots$ & $0.51-0.64$ & 0.57 \\
\hline 1,2-Dichloroethene (total) & $4 / 4$ & 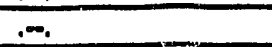 & $0.58-0.81$ & 0.68 \\
\hline 1-Elhyl-2-metbyl-benzzene & 22 & $=$ & $0.33-0.33$ & 0,33 \\
\hline 1-Methyt Naphrhalene & 22 & $\ldots$ & $0.068-0.069$ & 0.0685 \\
\hline 1.Penminol & $2 / 2$ & $m$ & $0.33-0.38$ & 0.355 \\
\hline 1h-Indeoc, 1-ethylindene & $1 / 1$ & $\therefore$ & $0.042-0.042$ & 0.042 \\
\hline 1h-Indeoe, 23-Dihydro-Mecbyl & $2 \sqrt{2}$ &.- & $0.033-0.06$ & 0.0465 \\
\hline 2-Buranone & $1 / 4$ & $0.2-0.5$ & $0.022-0.022$ & 0.022 \\
\hline 2-Merbylnaphthalone & $5 / 5$ & $\ldots$ & $0.076-0.092$ & 0.087 \\
\hline 3-0eranose & $2 \sqrt{2}$ & 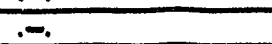 & $0.025-0.038$ & 0.0315 \\
\hline Aceoaplatbene & $5 / 5$ & $\therefore$ & $0.002-0.003$ & 0.0026 \\
\hline Aphes Activity & $1 / 5$ & $1-2$ & $1-1$ & 1 \\
\hline $\begin{array}{l}\text { Aluminum } \\
\text { Arocior-122, }\end{array}$ & $\begin{array}{l}3 / 5 \\
1 / 5\end{array}$ & $\begin{array}{l}0.04-0.104 \\
0.00057-0.0063\end{array}$ & $\begin{array}{l}0.091-0.144 \\
0.00071-0.00071\end{array}$ & $\begin{array}{l}0.12 \\
0.00071\end{array}$ \\
\hline Aroclor.1232 & $2 / 5$ & $0.00057-0.0054$ & $0.00091-0.0011$ & 0.001 \\
\hline Aroctor.1242 & $2 / 5$ & $0.00057-0.00025$ & $0.00069-0.00078$ & 0.000735 \\
\hline Arocar-1248 & $1 / 5$ & $0.00057-0.0006$ & $0.0038=0.0038$ & 0.0038 \\
\hline Banum & $5 / 5$ &. & $0.434-0.513$ & 0.46 \\
\hline Benrepe & 4/4 & $\ldots$ & $1.2-13$ & 1.2 \\
\hline Benzene 2-Ethyl-1,4-Dirnetbyl & $1 / 1$ & $\ldots$ & $0.033-0.033$ & 0.033 \\
\hline Baryllum & $1 / 5$ & $0.001-0.001$ & $0.001-0.001$ & 0.001 \\
\hline Bromseil (ACN) & $2 \boldsymbol{2}$ & $\ldots$ & $0.017-0.018$ & 0.0175 \\
\hline Butane, $1,1^{1}$-owybis (2,1 ethanediyloxy) bis & $7 \pi$ & ... & $0.64-1.6$ & 1.2 \\
\hline Butrine, 2-Mecbyl- & $4 / 6$ & & $0.27-0.45$ & 0.345 \\
\hline Cadminim & $1 / 5$ & $0.005-0.005$ & $0.005-0.005$ & 0.005 \\
\hline Calcium & $5 / 5$ & & $698-939$ & 823 \\
\hline Chrominum & $3 / 5$ & $0.01-0.01$ & $0.014-0.03$ & 0.02 \\
\hline Cobatt & 2/5 & $0.02-0.02$ & $0.021-0.032$ & 0.0265 \\
\hline Copper & $2 / 5$ & $0.01-0.01$ & $0,018-0,025$ & 0.0215 \\
\hline Di-i-busylphichalace & 25 & $0.011-0.012$ & $0.003-0.004$ & 0.0035 \\
\hline Diacetone Aloobol & $2 \Omega$ & $\ldots$ & $0.022-0.028$ & 0.025 \\
\hline Dibeorofuran & $3 / 5$ & $0.011-0.012$ & $0.002-0.003$ & 0.0027 \\
\hline Dietbyl Benaene & 1/1 & .. & $0.024-0.024$ & 0.024 \\
\hline Dimethyl Napethalene & $\sqrt[2]{2}$ & $\ldots$ & $0.015-0.032$ & 0.0235 \\
\hline Exbenyl Metbyl Benzeac & $2 \sqrt{2}$ & $\ldots$ & $0.05-0.08$ & 0.065 \\
\hline Echyt Dlmethy Benzene & $4 / 4$ & -- & $0.024-0.031$ & 0.027 \\
\hline Elfyd Methyl Benzene & $7 \pi$ &.- & $0.06-0.19$ & 0.14 \\
\hline Alby beprene & $4 / 4$ &. & $0.31-0.43$ & 0.37 \\
\hline Flucene & $5 / 5$ & 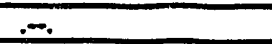 & $0.003-0.004$ & 0.0038 \\
\hline Breag 113 & $3 \sqrt{3}$ & $-\ldots$ & $1.9-2.8$ & 22 \\
\hline Freon 123 & $4 / 4$ & $=$ & $17-28$ & $2 \sqrt{15}$ \\
\hline Gatoma Activity & $2 / 5$ & $0-0$ & $0=0$ & 0 \\
\hline Hepeachlor eporide & 1/5 & $0.000057-0.00006$ & $0.00012-0.00012$ & 0.00012 \\
\hline Hydroperaxide, 1-Methylpentyl & 4/4 & . & $0.5-0.85$ & 0.703 \\
\hline Iran & 5/5 & .-. & $18.1-26.8$ & 21.5 \\
\hline
\end{tabular}


Table 1. Contaminants detected in Storm Drain SD-180-04 (new sampling point designation: SU-31) at the K-25 Facility, April 1990. All concentrations reported in units of $\mathrm{mg} / \mathrm{L}(\mathrm{ppm})$ except alpha and gamma activity $(\mathrm{pCi} / \mathrm{L})$. Underlining indicates chlorinated volatiles and aromatic compounds that may be degraded to some extent in the bioreactor.

(continued)

\begin{tabular}{|c|c|c|c|c|}
\hline Chemical & $\begin{array}{l}\text { Number } \\
\text { detected }\end{array}$ & $\begin{array}{c}\text { Range of } \\
\text { detection } \\
\text { limits }\end{array}$ & $\begin{array}{c}\begin{array}{c}\text { Values above } \\
\text { detection } \\
\text { limits }\end{array} \\
\end{array}$ & $\begin{array}{c}\text { Average } \\
\text { value }\end{array}$ \\
\hline Meloryogcloburane & $1 / 1$ & $\ldots$ & $0.3-0.3$ & 0.3 \\
\hline Mernverclopentane & $2 \sqrt{2}$ & $\infty$ & $0.17-0.18$ & 0.175 \\
\hline Metbrlene Chloride & $\sqrt[3]{4}$ & $0.1-0.1$ & $0.16-0.46$ & 0.31 \\
\hline Merbylpropyl Benzene & $6 / 6$ & $\therefore$ & $0.014-0.038$ & 0.026 \\
\hline Mobybdenum & $1 / 2$ & $0.02-0.02$ & $0.185-0.145$ & 0.145 \\
\hline Naphenalene & $5 / 5$ & - & $0.093-0.13$ & 0.11 \\
\hline Naphinalene, -Dimeshul- & $3 \sqrt{3}$ & 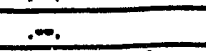 & $0.017-0.024$ & 0.02 \\
\hline Nickel & $1 / 5$ & $0.02-0.02$ & $0.02-0.02$ & 0.02 \\
\hline Pencane & $3 / 3$ & $\ldots$ & $0.31-0.55$ & 0.44 \\
\hline Phepanchreoe & $5 / 5$ &.- & $0.004-0.005$ & 0.0042 \\
\hline Potascium & $4 / 5$ & $1.2-1.9$ & $223-273$ & 25 \\
\hline Propane,2-Metbony-2-Metbyl & $2 / 2$ & - & $0.11-0.15$ & 0.13 \\
\hline Propenyl Bepresse & $1 / 1$ & . & $0.077-0.077$ & 0.077 \\
\hline Silloon & $2 / 2$ & $\therefore$ & $4.21-6.1$ & 52 \\
\hline Silver & $2 / 5$ & $0.005-0.005$ & $0.006-0.133$ & 0.0695 \\
\hline Sotium & s/s & $-\infty$ & $11.1-15.2$ & 13.1 \\
\hline Stroouum & $2 \Omega$ &. & $0.053-0.105$ & 0.079 \\
\hline Tetrectioroechene & $2 / 4$ & $0.25-0.25$ & $0.063-0.067$ & 0.065 \\
\hline Tetramezhyt Benzene & $4 / 4$ &. & $0.02-0.031$ & 0.023 \\
\hline Tharium & T/2 & $0.05-0.05$ & $0881-0.881$ & 088 \\
\hline Toluese & $4 / 4$ & $\ldots$ & $27-3.1$ & 20 \\
\hline Trictloroethene & $4 / 4$ & 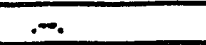 & $0.33-0.43$ & 0.385 \\
\hline Inimedhy berzene & $21 / 21$ & $\cdots$ & $0.058-0.46$ & 0.16 \\
\hline Unknow & $21 / 21$ &.- & $0.017-0.055$ & 0.033 \\
\hline Uaknown Hydrocarbon & $28 / 28$ & .- & $0.018-0.23$ & 0.060 \\
\hline Uravium 238 & $1 / 2$ & $0.2-0.2$ & $4.44-4.44$ & $\$ .44$ \\
\hline Vamadium & $3 / 5$ & $0.01-0.01$ & $0.01-0.014$ & 0.0127 \\
\hline Xylene (coeal) & $4 / 4$ & $\therefore$ & $1.4-1.9$ & 1.625 \\
\hline Zac & $4 / 5$ & $0.01-0.01$ & $0.01-0.068$ & 0.042 \\
\hline 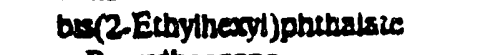 & 1/5 & $0.011-0.012$ & $0.004-0.004$ & 0.004 \\
\hline Do-Prophloemene & $6 / 6$ & $\therefore$ & $0.031-0.86$ & 0.17 \\
\hline Lead & $2 / 5$ & $0.03-0.03$ & $0.036-0.041$ & 0.0385 \\
\hline Magnesium & 5/5 & $\cdots$ & $9.78-129$ & 11.3 \\
\hline Mangraese & $5 / 5$ & . & $11.4-13.7$ & 127 \\
\hline Methyt Methyl Ethyl Bemzene & $1 / 1$ & $\ldots$ & $0.036-0.036$ & 0.036 \\
\hline Methyl Naphthalene & $1 / 1$ & 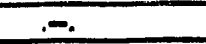 & $0.044-0.044$ & 0.044 \\
\hline Mechyl Propenyl Benzene & $3 / 3$ &. & $0.019-0.035$ & 0.024 \\
\hline
\end{tabular}

Source: D. Miller, personal communication to S. E. Herbes, 10/8/90. Exerpted from "Site Characterization Summary: K-1070-C/D Classified Burial Ground." Report No. K/ER4/D1 (Draft): Appendix C (Surface Water Sampling Data). Environmental Restoration Division/ K-25 Environmental Restoration Program, March 1990. 
this technology at the pilot-scale will help to validate performance expectations and to encourage further application to DOE's environmental remediation and waste management problems.

\section{BIODEGRADATION CHEMISTRY}

Cometabolism is the term generally applied to the phenomenon in which utilization of a primary substrate enables the simultaneous (co)metabolism of another species that alone is unable to support growth and maintenance of the microorganisms. Chlorinated solvents are known to be degraded by these mechanisms. Methanotrophs are able to degrade TCE via a nonspecific enzyme called methane monooxygenase (MMO), whose principal function is to oxidize methane to provide energy for the microbial cells. MMO will also convert TCE to an epoxide; the epoxide is relatively unstable and spontaneously hydrolyzes to form several other chlorooxygenated compounds that are further biodegraded relatively easily by other microorganisms. ${ }^{1}$ The process is represented below.

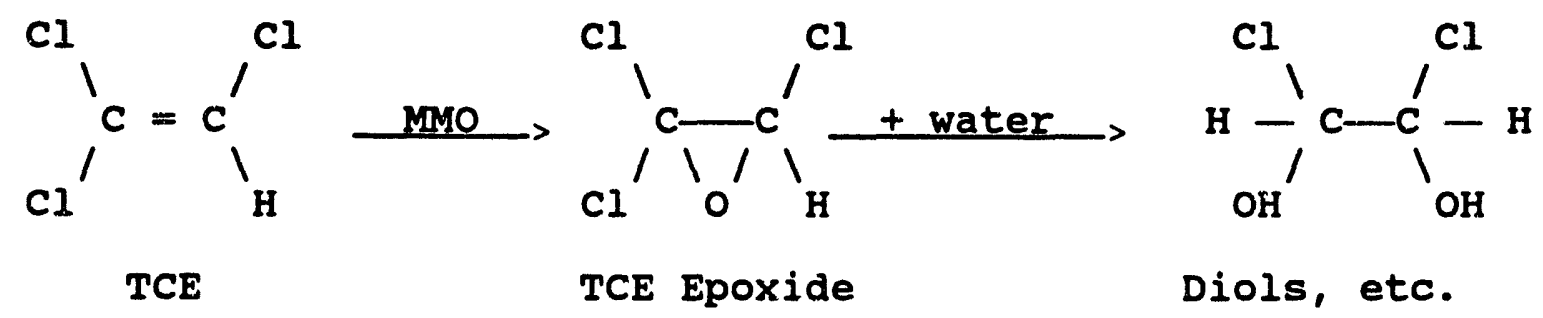

Certain toluene-degrading microorganisms are also known to degrade TCE by a cometabolic pathway using another nonspecific enzyme, toluene dioxygenase.

PCE and other chlorinated alkanes such as 1,1-dichloroethane (1,1-DCA) and 1,1,1trichloroethane (1,1,1-TCA) are believed to be recalcitrant to oxidation in an aerobic environment, but they are degraded anaerobically by reductive dehalogenation mechanisms. 
Nevertheless, researchers at the University of Tennessee have seen apparent degradation of these compounds in an aerobic biofilm reactor. ${ }^{2}$ They postulate that degradation occurs in anaerobic niches within the biofilms. Thus, it is not known a priori if these and other compounds in the K-25 seep water will be degraded in the pilot-scale bioreactors. These compounds will be monitored in the seep water and bioreactor effluents to determine if degradation occurs.

\subsection{SCOPE OF PILOT-SCAIE FIEILD TESTS}

This interim report is a summary of the start-up phase and the initial operating campaign for the methanotrophic technology using an upgraded bioreactor system on loan from the AFCESA, Tyndall Air Force Base, Florida. ORNL has been a leader in the development of this technology through the applied research and bench-scale phases. Scaleup for the field demonstration was based on process development work. 3,4

The objectives of these field tests are to:

1. demonstrate stable operation of the bioreactor and associated equipment, including the pretreatment and effluent polishing steps; and

2. evaluate the biodegradation of TCE and other organics in the seep water for the three operating modes - air oxidation pretreatment, steam stripping pretreatment, and no pretreatment.

Operation of the pilot-scale process equipment will continue to further characterize and improve the process performance. Further data analysis and interpretation will be undertaken. Development and testing of the second cometabolic technology, based on toluene-degrading microorganisms, is planned for the second phase of the project after demonstration of the methanotrophic terhnology. The ultimate goal is to demonstrate both technologies side by side. Additional detailed informaticn concerning this technology 
demonstration can be found in the test plan, ${ }^{5}$ which includes the Safety Assessment, Health and Safety Plan, Waste Management Plan, and Quality Assurance/Quality Control (QA/QC) Plan.

\subsection{PROJECT OVERVIEW AND CHRONOLOGY}

A list of the major events and dates associated with the pilot-scale phase of this program is given in Table 2. From March through August 1992, the focus has been on the air oxidation pretreatment mode. Operation in the steam stripping mode will be conducted in September 1992, and continued operation beyond this date will be pursued as funding permits.

\section{PROCESS EQUIPMENT DESCRIPTION}

\section{BIOREACTOR SKTD UNTT}

The bioreactor skid unit was loaned from the AFCESA. It is one of three essentially identical units constructed by Battelle Columbus for the AFCESA for field tests at Tinker AFB, Oklahoma, using methanotrophic microorganisms for cometabolism of TCE in groundwater. (ORNL provided a microbial culture to Battelle for inoculation of the bioreactors for the Tinker AFB tests.) One of the three units is presently being used by the AFCESA for in-house development work, and the third unit is on loan to the DOE Savannah River Laboratory for groundwater treatment studies.

As received from the AFCESA, the skid contained two stainless steel (SS) bioreactor columns $-1 \mathrm{ft}$ in diameter and $6 \mathrm{ft}$ tall, mounted on a structural support frame, with an electrical control panel; a nutrient addition tank; and miscellaneous flow meters, pumps, and sensors. The piping, flow meters, sensors, controllers, and pumps were upgraded at ORNL 
Table 2. Major events during cometabolic bioreactor demonstration

\begin{tabular}{|l|c|}
\hline \multicolumn{1}{|c|}{ EVENT } & DATE \\
\hline Received Bioreactor Skid From AFCESA & $8 / 90$ \\
Obtained Van Trailer & $3 / 91$ \\
Completed Installation of Skid In Trailer and Equipment Checkout & $8 / 91$ \\
Completed Safety Review & $8 / 91$ \\
Transported Trailer from ORNL to K-25 Site & $8 / 91$ \\
Completed Installation at K-25 Site & $9 / 91$ \\
Received Approval for RCRA'90-day and Satelite Waste & \\
\multicolumn{1}{|c|}{ Accumulation Areas } & $9 / 91$ \\
Completed Readiness Review and Received Approval to Operate & $9 / 91$ \\
Inoculated Bioreactors & $9 / 20 / 91$ \\
First Introduction of Seep Water & $9 / 27 / 91$ \\
Total Shutdown -- Insufficient Funds & $12 / 3 / 91$ \\
Receipt of FY 1992 Funds (authorization to proceed) & $2 / 15 / 92$ \\
Reinoculation & $3 / 5 / 92$ \\
Introduction of Seep Water - Air Oxidation Mode & $5 / 28 / 92$ \\
Shutdown (total recycle) - Land Disposal Restrictions Alert & $6 / 6 / 92$ \\
Resume Treatment of Seep Water & $6 / 18 / 92$ \\
Replacement of Main Feed Pump & $7 / 1 / 92$ \\
Shutdown for Waste Disposal (total recycle) & $7 / 6 / 92$ \\
Resume Treatment of Seep Water & $8 / 3 / 92$ \\
Shutdown for Waste Disposal (total recycle) & $9 / 1 / 92$ \\
Resume Treatment of Seep Water - Steam Stripping Mode & TBD \\
\hline & \\
\hline & \\
\hline & \\
\hline
\end{tabular}


to provide several different operating modes, as described later. The process flow diagram is shown in Fig. 1. Both bioreactor columns operate as trickle bed bioreactors; they can be operated in series, in parallel, or individually. The ceramic Raschig ring packing in the columns was removed, and a structured packing obtained from Koch Engineering (Fig. 2a) was installed in both columns. The structured packing is constructed of a woven gauze fabric of polypropylene and polyacrylonitrile. This packing is designed to maintain uniform liquid distribution over the surface area at low flow rates. The liquid distributor used by Battelle (Fig. 2b) was cleaned and reinstalled at the top of each column. A new nutrient feed tank, constructed frum a 30-gal stainless-steel drum, was installed.

\section{PRETREATMENT SYSTEMS}

Two pretreatment systems were added (see process flow sheet in Fig. 1) to prevent iron in the seep water [typically $20 \mathrm{mg} / \mathrm{L}$; (see Table 1)] from entering the bioreactor columns (where it would oxidize and precipitate, likely interfering with the biofilms and perhaps plugging the bioreactor). One pretreatment system is an air oxidation system, purchased locally from Continental Water Systems, for iron removal from the seep water. The second pretreatment system is a steam stripper. This unit removes the organics from the seep water for treatment in the bioreactors, while the iron remains with the seep water. The steam stripper was designed and constructed at ORNL and installed on the bioreactor skid frame. The stripper is an insulated column 6 in. in diameter and $8 \mathrm{ft}$ tall, packed with 5/8-in. stainless-steel pall rings.

\section{FIFID INSTALLATION}

The bioreactor skid and pretreatment equipment were installed in a van-type trailer (Fig. 3). The trailer is located at the parking lot just east of Building K-1098-D at the K-25 


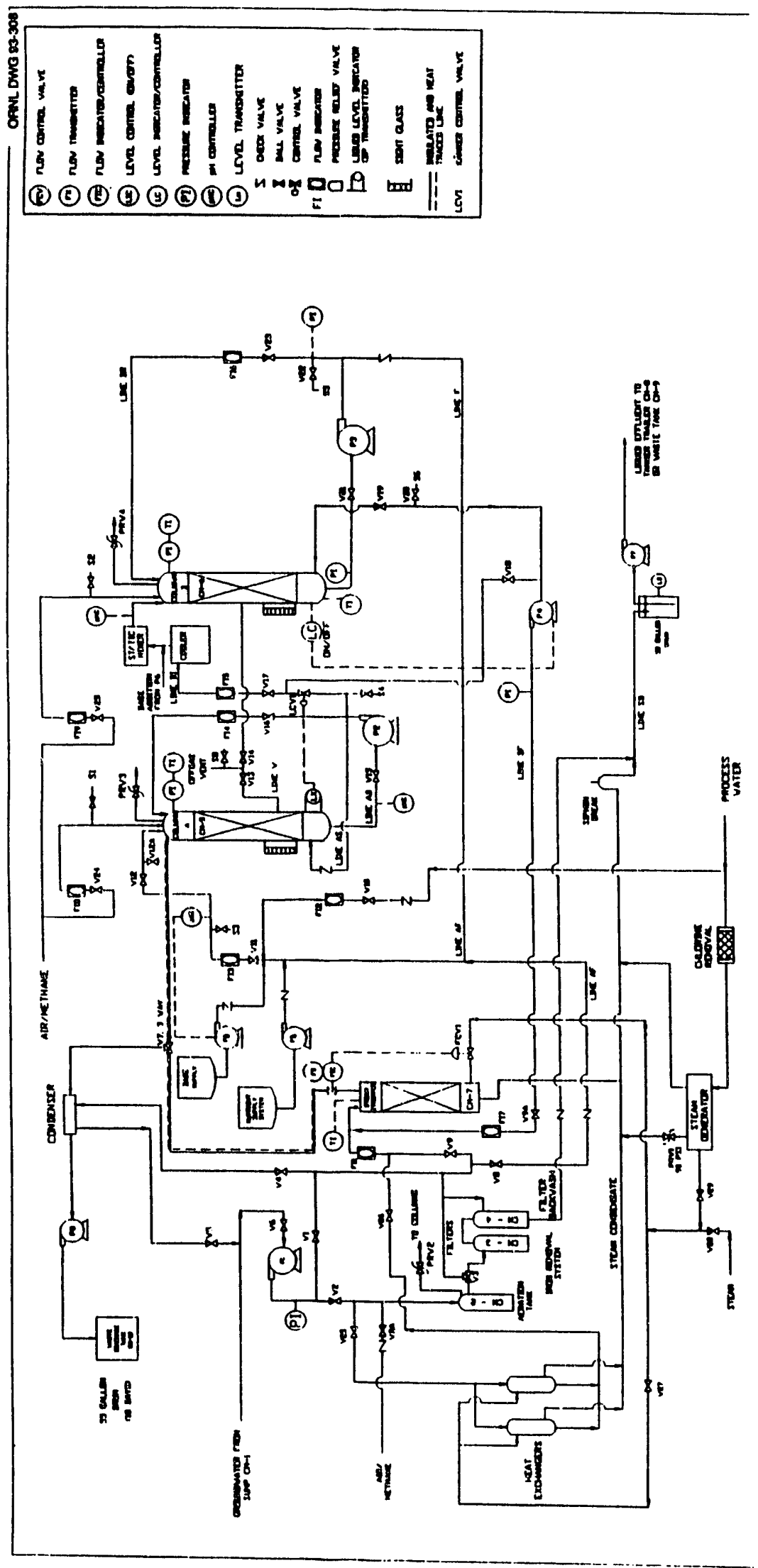

总 


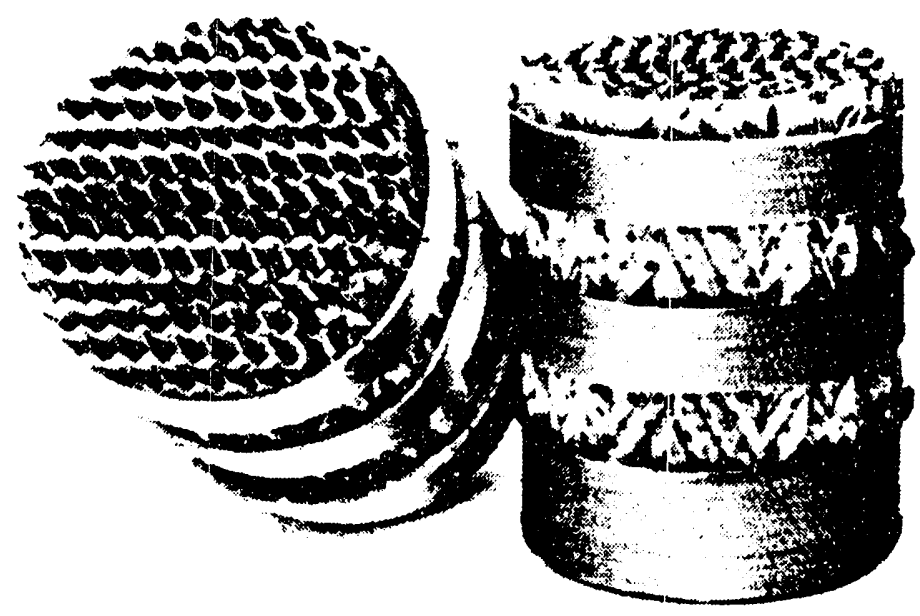

(a)

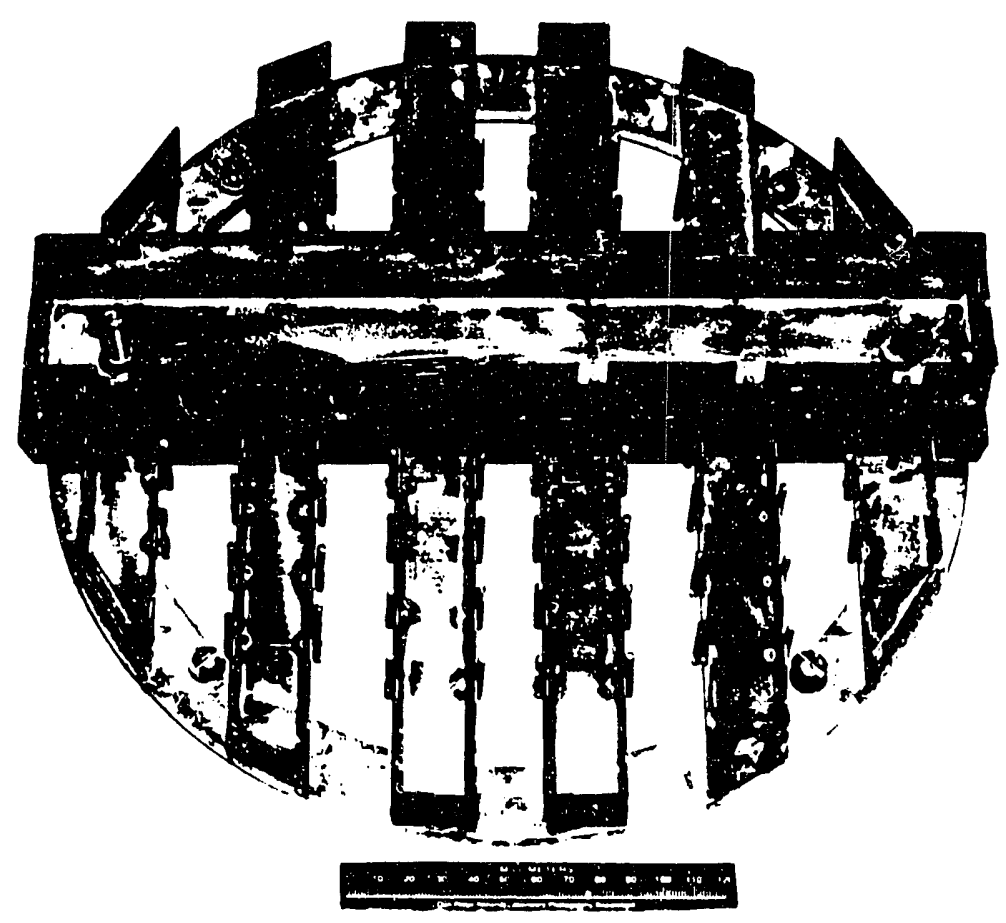

(b)

Fig. 2. Koch packing (a) and liquid distributor (b) in the bioreactor columns. 


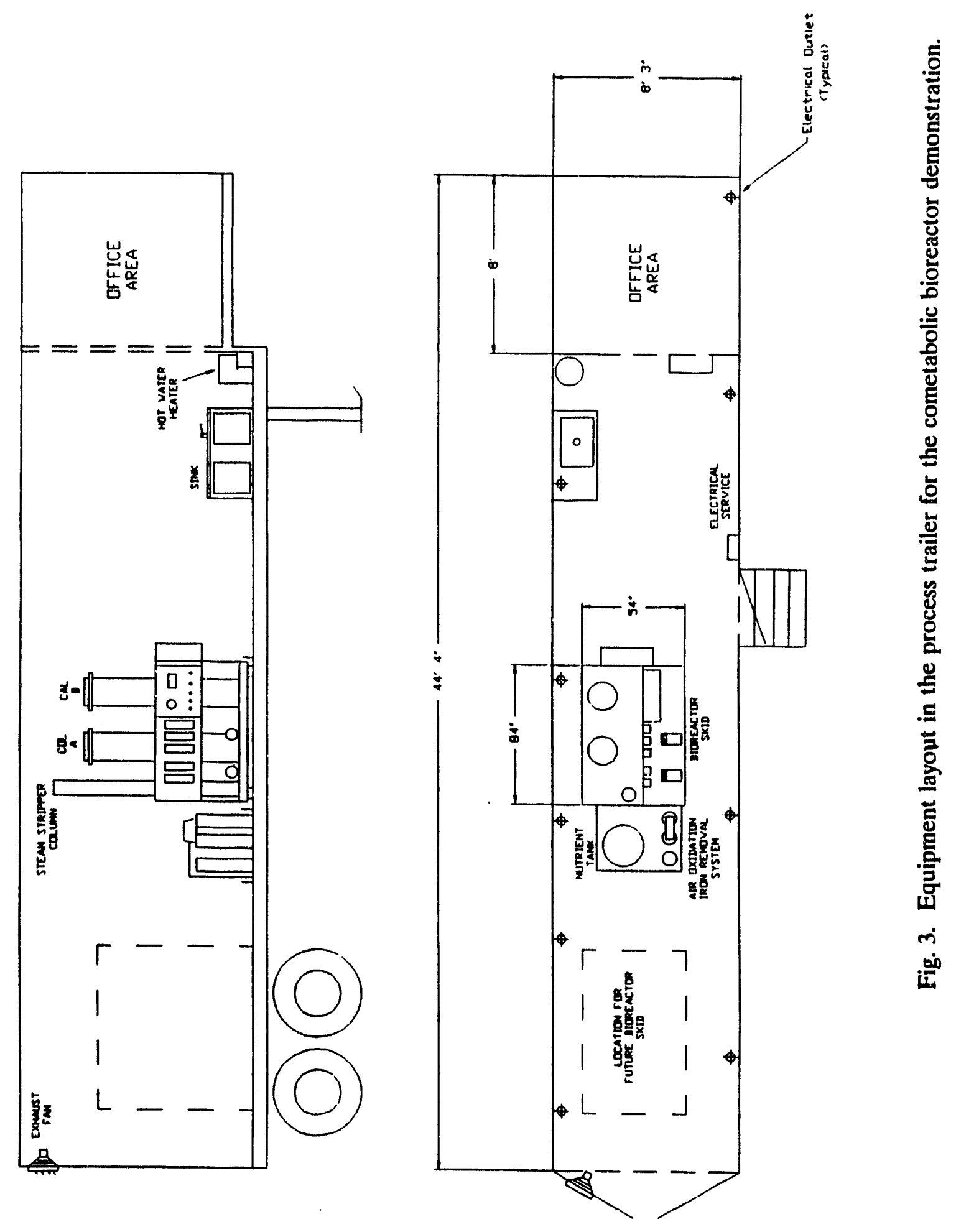


Site and on the west side of Avenue D (Fig. 4). Electrical service (3 phase, $240 \mathrm{~V}, 100 \mathrm{~A}$ ) is obtained at a pole beside the trailer. Premixed $3 \%$ methane in air is provided from compressed gas cylinders outside the trailer. Water from the K-1070-C/D seep on the east side of Avenue D is collected in an 5-gal covered container (to minimize volatilization losses) and piped across the street via a 1/2-in.-diam stainless line covered with a traffic ramp on the street. The feed pump is located in the trailer. Steam for the steam stripper was originally provided via a flexible hose from the utility steam service at Building K-1098-D. However, a stand-alone electrical steam generator has been installed in the trailer to provide a cleaner steam supply for the steam stripper pretreatment mode. The process steam from K-1098-D will be used to preheat the seep feed for that operating mode. Off-gas from the bioreactors, containing $<1 \%$ methane in air and parts per million levels of VOCs, is vented to the environment outside the trailer. The 6300 -gal tanker trailer for effluent storage and a 1500-gal polypropylene surge ta:k are located in a 90-d Resource Conservation and Recovery Act (RCRA) storage area immediately adjacent to the process trailer. In the air oxidation and no-pretreatment modes, the effluent water from the bioreactors is treated in the steam stripper (described previously) to minimize residual organics in the wastewater sent to the CNF. These stripped organics are collected in a 55-gal drum designated as a RCRA satellite waste accumulation area.

\section{WASTE DISPOSAL}

Prior to disposal, all major aqueous effluent streams are treated using the steam stripper to remove VOCs. This step is part of the main process operation for the steam stripping pretreatment mode. For the other modes, the steam stripper is used as an effluent polishing step. After steam stripping, liquid effluents are routed to a 6300 -gal tanker trailer located at the site and ultimately transported to the CNF at the K-25 Site for discharge 

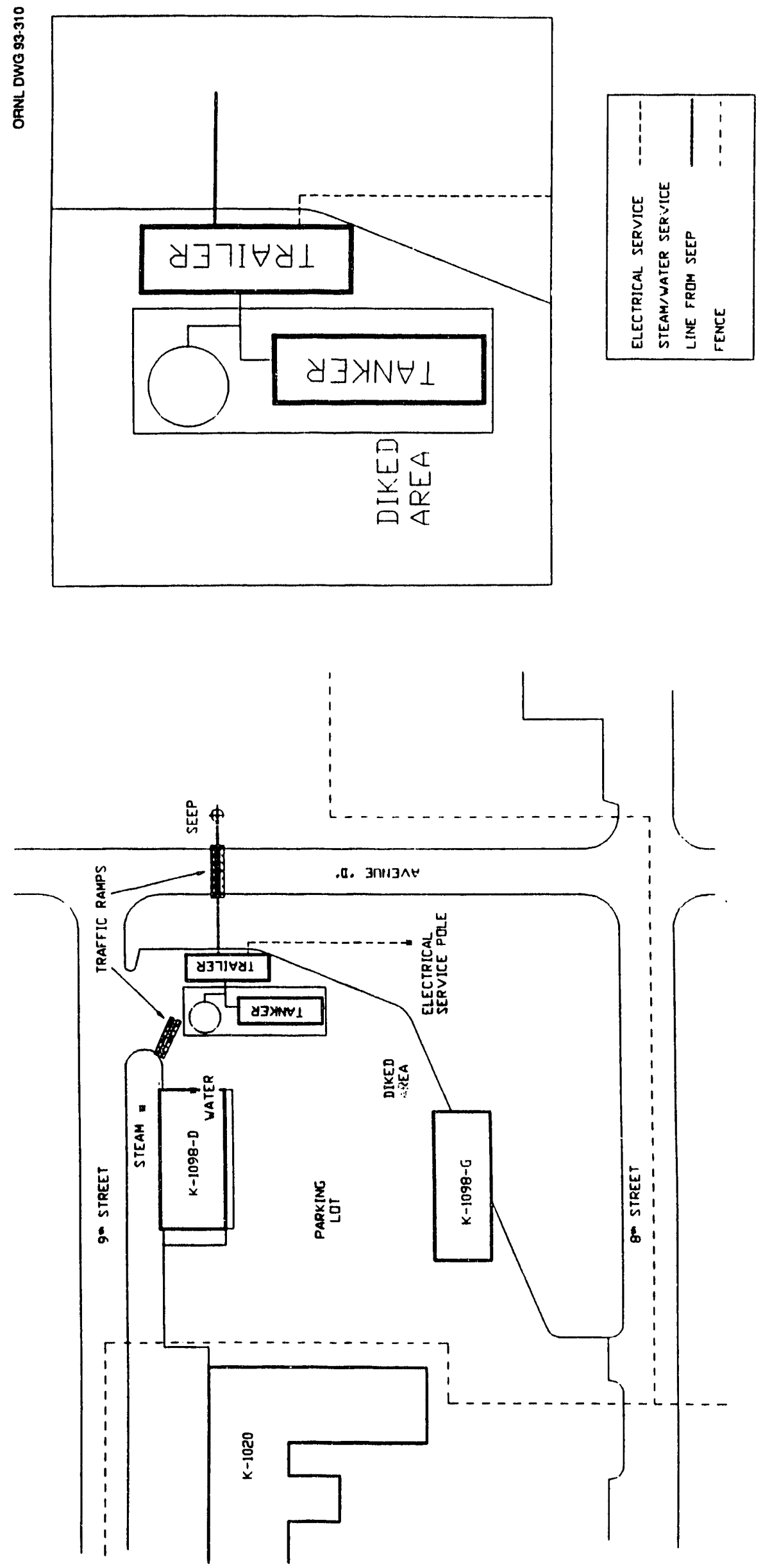

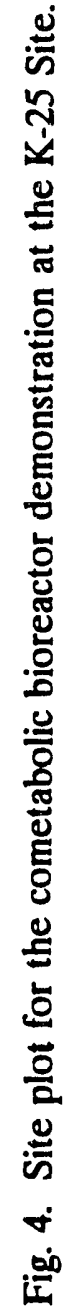


through an NPDES-permitted point. The waste management plan requires that this treated water in the tanker be sampled and analyzed to ensure compliance with the CNF waste acceptance criteria (Table 3) before it is released to the CNF.

\section{OPERATING MODES}

\subsection{STEAM STRIPPING PRETREATMENT}

This operating mode is depicted in Fig. 5. Raw seep water is applied to the top of the packing, and steam is added at the bottom via an automatic control valve to produce only a very small quantity of overhead vapor ( $\sim 5 \%$ of the seep water feed). This vapor contains $\sim 99 \%$ of the volatile organics and is sent to the bioreactors, which are op rated in series in essentially total recycle. A small liquid purge stream, equal in mass to the vapor rate entering the bioreactors, is sent back to the top of the steam stripper to maintain a constant liquid volume in the bioreactor recycle loop. Meanwhile, the seep water exits the bottom of the steam stripper, stripped of organics but still containing iron, other minerals, and nonvolatiles. This water is sent to the tanker trailer for ultimate disposal at the CNF.

\section{AIR OXIDATION PRETREATMENT}

A simplified block flow sheet for this mode is shown in Fig. 6. Air is bubbled through the seep water in one tank/column to oxidize the iron, and then the ferric hydroxide is removed in a second sand filter column. Effluent water from the sand filter is then sent to the trickle filter bioreactors. The sand column is backwashed periodically (on an automatic timer circuit) to remove the precipitates. The air feed to the oxidation unit is the same air/methane gas mixture for the bioreactors; the off-gas from the oxidation unit is fed to the first bioreactor (Column A) to maintain the methanotrophic microorganisms. This 
Table 3. Waste acceptance criteria for the Central Neutralization Facility

\begin{tabular}{|c|c|}
\hline CONSTITUENTS & CRITERION (mg/l) $)$ \\
\hline Cadmium & 2.6 \\
\hline Chromium & 2.89 \\
\hline Copper & 20.7 \\
\hline Lead & 14.3 \\
\hline Nickel & 17 \\
\hline Silver & 1.2 \\
\hline Zinc & 9.25 \\
\hline Cyanide & 0.65 \\
\hline Total toxic organics & 2.13 \\
\hline Oil and grease & 26 \\
\hline Total suspended solids & 270 \\
\hline
\end{tabular}




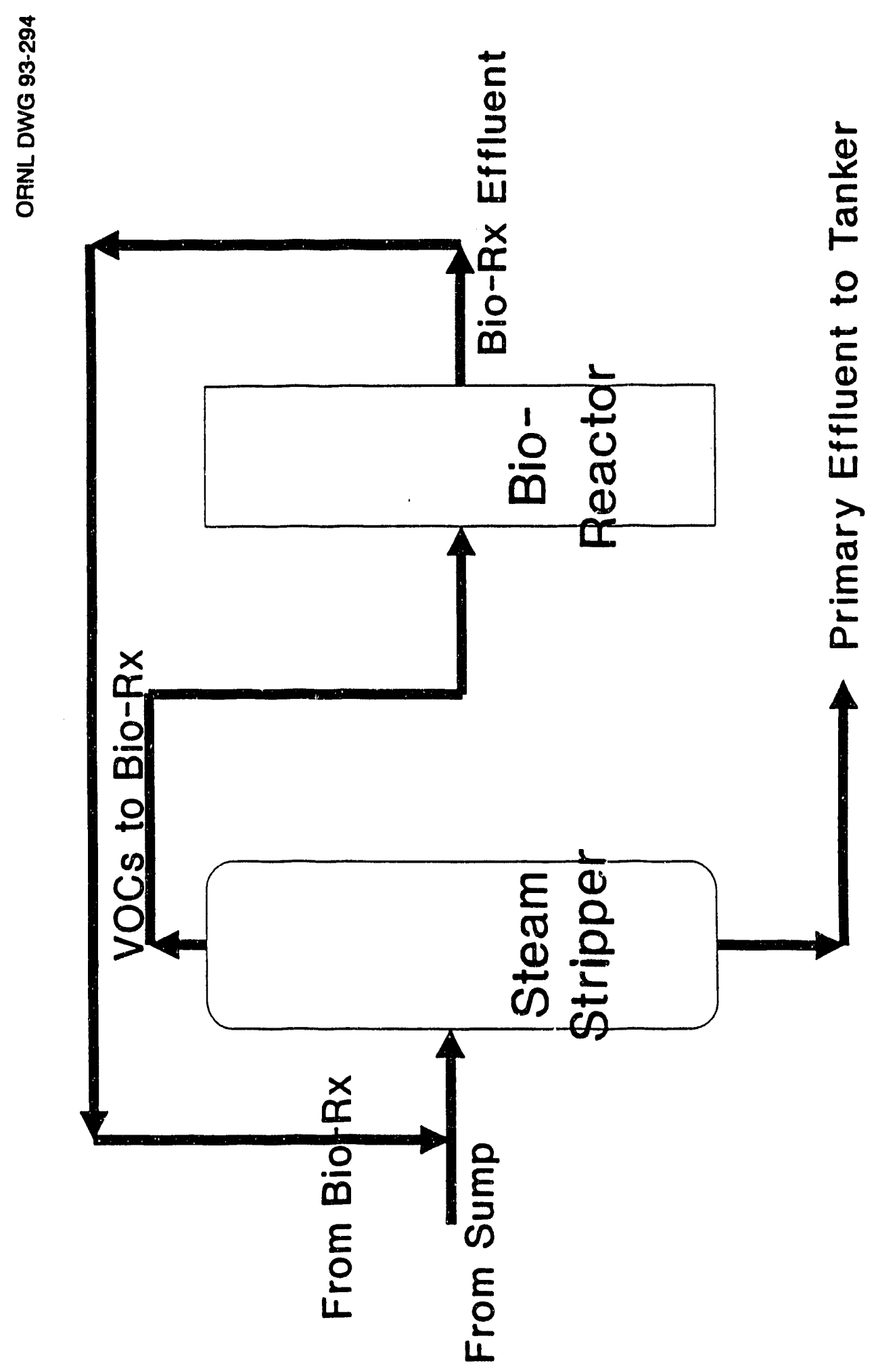

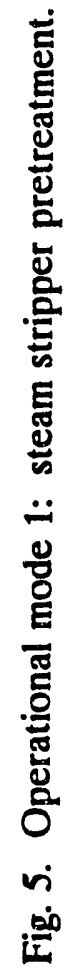




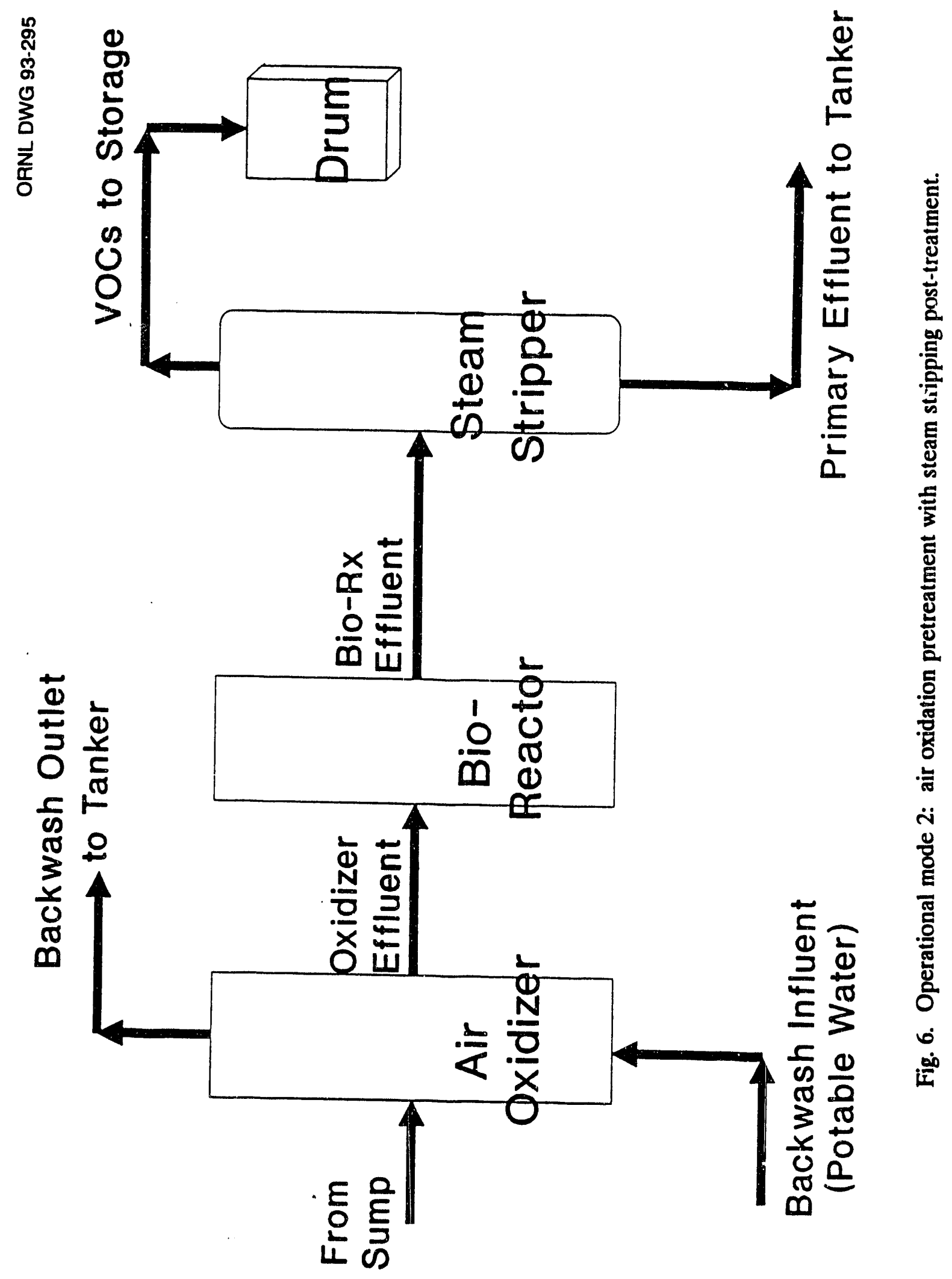


configuration allows for biotreatment of organics stripped from the seep water in the air oxidation unit. For this technology demonstration, the treated water from the bioreactors is polished with the steam stripper, as described previously, before it is sent to the tanker trailerfor storage and analysis and eventual treatment at the CNF. Actual implementation of this technology for this or other applications may or may not require effluent polishing, depending on process performance and the applicable regulations for discharge of the treated water.

\subsection{NO PREIREÁTMENT}

This mode is the simplest and requires the least equipment (Fig. 7). Tests wi" be conducted to detcimine if this mode is practical for tieatment of water containing significant iron. Raw seep wate is fed directly to the bioreactors, which may be operated with some liquid recycle to ticrease the hydraulic residence time if necessary. For this technology demonstration, the effluent is treated with the steam stripper as in the air oxidation pretreatment mode.

\section{PROCESS MONITORING AND SAMPLING}

\subsection{PROCESS CONTROL AND PERFORMANCE}

The process equipment provides the capability to obtain liquid and gas samples at many different locations. For routine process monitoring, liquid and gas sainples are obtained periodically at seven different locations, shown schematically in Fig. 8, for the steam stripping mode. Liquid samples are obtained from the seep water feed line (L1), the treated effluent water to the tanker trailer (L2), the liquid flow between the two bioreactors (L3), the liquid 


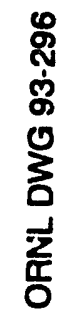
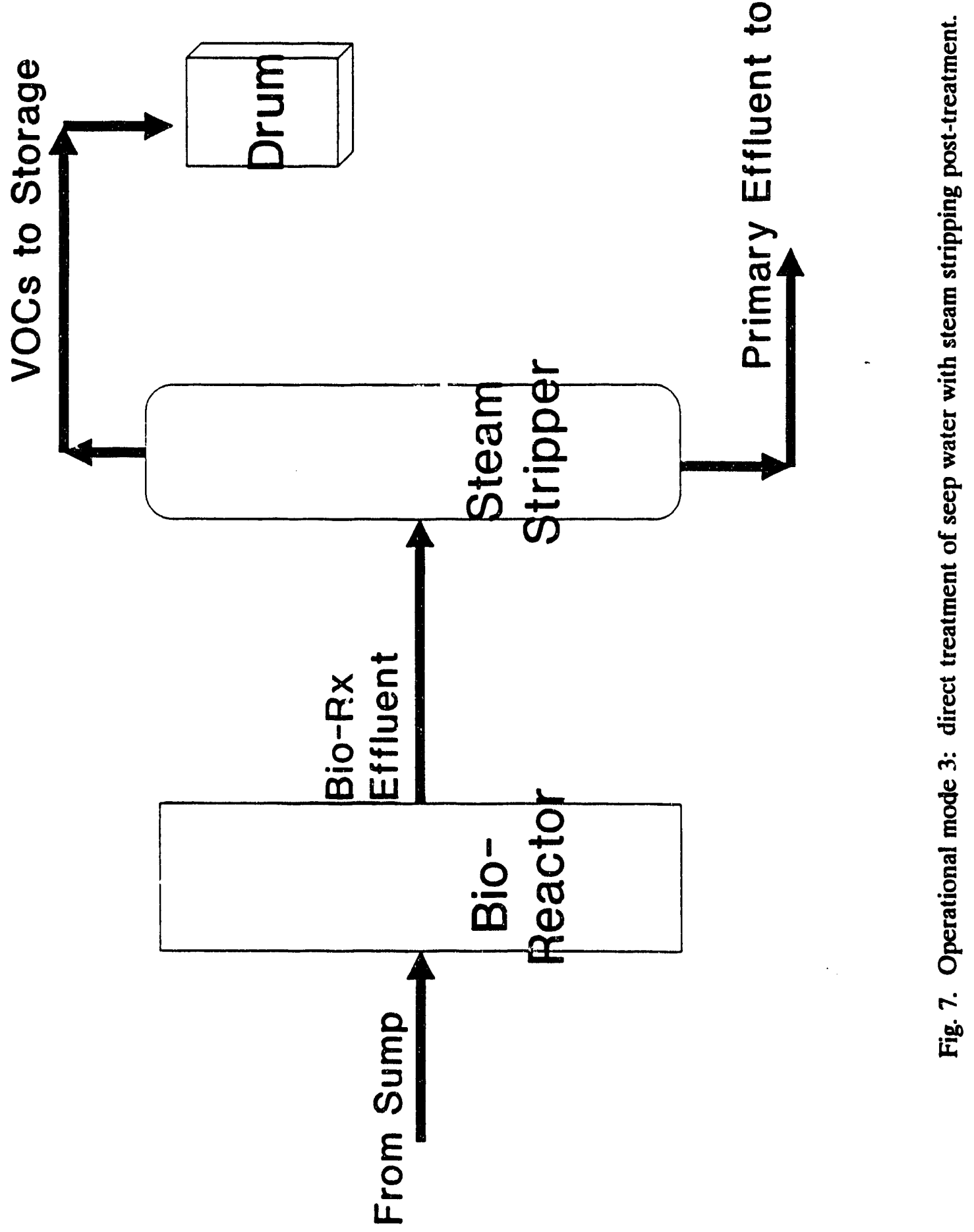


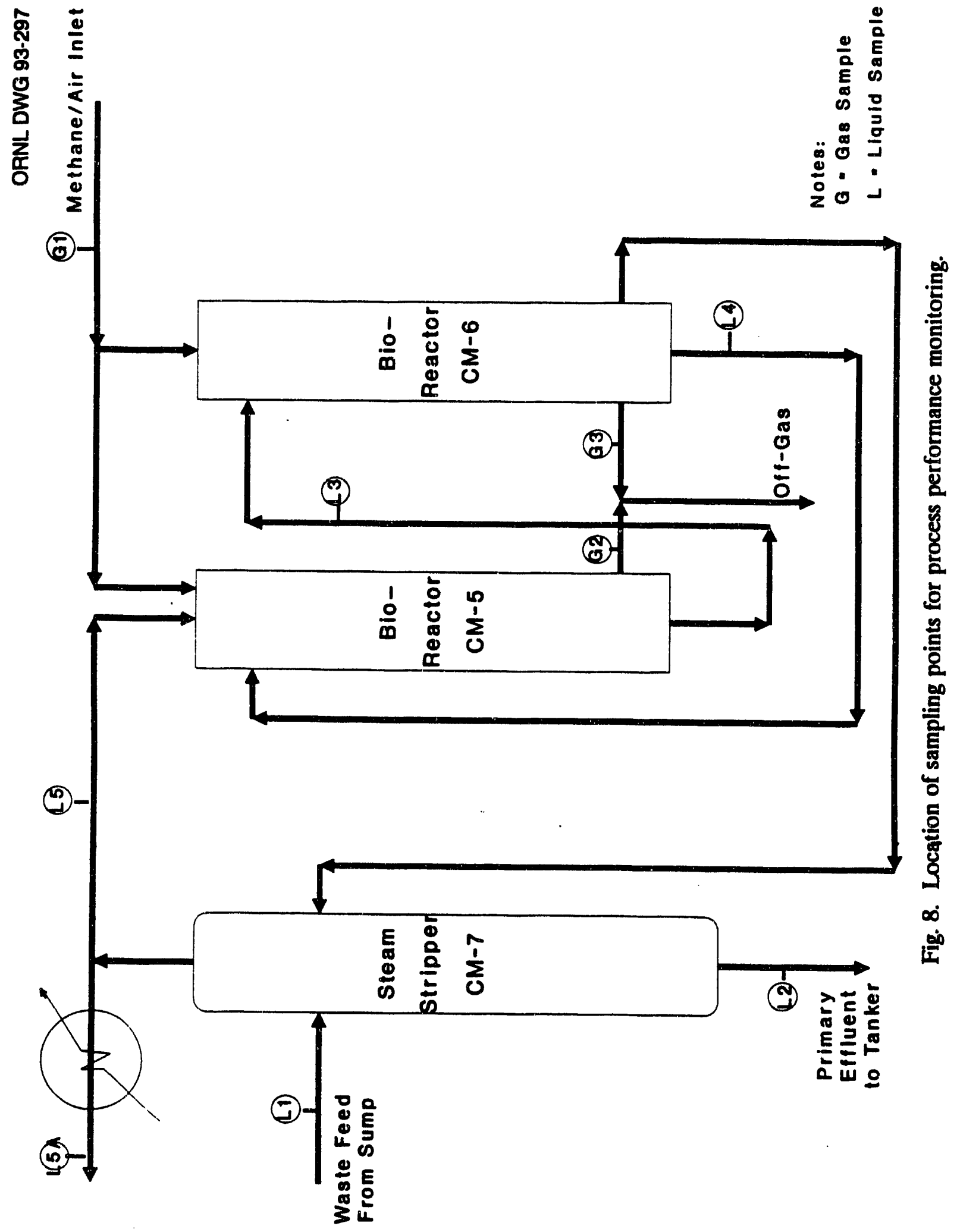


effluent from the second bioreactor (LA), and the overhead vapor from the steam stipper (L5). Gas samples are obtained from the methane/air feed stream (G1) and the off-gas streams from each bioreactor column (G2 and G3). Locations L2 and L5 are not sampled routinely in the air oxidation and no-pretreatment modes because they are not directly related to process performance.

During start-up of the process equipment, two sets of samples were collected per day to obtain more information on process performance during the critical start-up period. During routine stable operation, one set of samples per day is judged to be adequate to monitor the process performance. In addition to the liquid and gas samples described previously, the other operating conditions such as flow rates, temperatures, and $\mathrm{pH}$ were noted and recorded by the project staff during daily visits to the process trailer.

Several other parameters are measured periodically to aid in interpreting the VOC concentration data in terms of biodegradation. Samples of the liquids obtained from ports $\mathrm{L} 1$ through LA are assayed for nutrients (nitrate, ammonia, and phosphate) and biomass (as volatile suspended solids). Liquid samples are submitted periodically to Analytical Chemistry at K-25 for analysis of VOCs to serve a QAVC function in support of the daily process monitoring and sample analyses carried out by project staff.

\section{WASTE DISPOSAL}

Analysis of the treated effluent in the tanker trailer is required to ensure that the waste acceptance criteria for the CNF are met (Table 3). Upon request from the project engineer, the K-25 staff sample the tanker and submit the samples for analysis. 


\section{ANALYTICAL METHODS}

\subsection{ORNL SUPPORT LABORATORY}

\subsubsection{Liquid Samples}

Liquid samples were analyzed using a Hewlett Packard (HP) 5890 gas chromatograph equipped with an electron-capture detector, located in Building 3017. The response of the detector was plotted and integrated with a HP model 3396A recording integrator. Separation was achieved with an AT-624 $60-\mathrm{m}$ by $0.53-\mathrm{mm}$ I.D. capillary column with $1-\mu \mathrm{m}$ film thickness (Alltech, Inc.).

Liquid samples were collected using a separate $25-\mathrm{mL}$ gastight syringe for each sample point. The syringe was first rinsed with the sample and then emptied. A 12-mL sample was then taken and injected into a $40-\mathrm{mL}$ amber bcrosilicate vial containing $12 \mathrm{~mL}$ of hexane and $8 \mathrm{~mL}$ of acetone. The acetone partitioned wholly into the water and prevented formation of a hexane-water emulsion. The vials were sealed using screw-cap closures with a Teflon-faced silicone rubber seal. These samples and a blank containing deionized water were extracted overnight on a rotator. Approximately $1.5 \mathrm{~mL}$ of the hexane phase was then pipetted into a 2-mL autosampler vial and sealed with a crimp-type septum seal. The vials were then placed on the autosampler tray for an HP Model 7673A automatic sampler/injector. The integrator was programmed to calculate the concentrations of the target organics based on calibration with known standards.

The gas chromatograph was recalibrated weekly using standards prepared from a certified standard mix purchased from RESTEK, Inc., to EPA specifications. The calibration mix contained $2000 \mathrm{mg} / \mathrm{L}$ of each of the target compounds (TCE; 1,1,1-TCA; 1,2-trans-DCE; 
PCE; 1,1-DCA; and methylene chloride) prepared in purge-and-trap grade methanol. These mixes were then diluted with hexane or water to make calibration standards in the concentration range of $1 \mu \mathrm{g} / \mathrm{L}$ to $1000 \mu \mathrm{g} / \mathrm{L}$. The detection limits are estimated to be $1 \mu \mathrm{g} / \mathrm{L}$ for TCE; 1,1,1-TCA; and PCE in liquid and gas samples and $200 \mu \mathrm{g} / \mathrm{L}$ in liquid samples and $100 \mu \mathrm{g} / \mathrm{L}$ in gas samples for 1,1-DCA. The headspace gases in the extraction vials were assayed for VOCs; none were found. Furthermore, selected standards prepared in hexane gave results identical with standards prepared in water. On this basis, it is assumed that the extraction procedure recovered essentially all of the VOCs in the aqueous samples.

\subsubsection{Gas Samples}

Gas samples were analyzed for the target organics using the gas chromatograph described previously without the autosampler. Gas samples were obtained for both methane and organics analysis using 2-L Tedlar bags. Five- $\mathrm{L}$ samples from the Tedlar bags were injected into the gas chromatograph using a $10-\mu \mathrm{L}$ gastight syringe. The Tedlar bags were then purged with ambient air and evacuated before reuse. Ambient air blanks were periodically run to verify that no cross contamination was occurring between uses. The integrator contained a separate program to calculate the concentrations based on runs with known standards. The calibration standards were prepared from the certified standard mix described previously.

\section{K-25 ANALYTICAL LABORATORY}

During stable operation, samples of gas and liquid streams are submitted periodically to the K-25 Analytical Laboratory for VOC assays by approved EPA standard methods. These results serve a QA function for results of our own process monitoring. (No samples 
have yet been submitted for this purpose.) Samples for characterization of the effluent tanker contents have been assayed by the K-25 Analytical Laboratory, and our target VOCs were found to be below detectable limits. However, the mixed contents of the tanker are not necessarily representative of the treated water discharged from the bioreactors for a variety of reasons, including steam stripping of the bioreactor effluent, possible volatilization of VOCs during transfers, and addition of uncontaminated rainwater from the diked area to the tanker.

\section{DATA MANAGEMENT AND ANALYSIS}

Concentration data for VOCs were entered into a Lotus ${ }^{\circledR}$ spreadsheet along with the liquid and gas flow rates for each column, $\mathrm{pH}$, temperature, and additional comments concerning operation of the system. The spreadsheet automatically calculates a percent degradation for each compound detected. The degradation is calculated from a steady-state material balance around each bioreactor. The amounts of each compound leaving the bioreactor in the off-gas and liquid streams are subtracted from the amount entering, and the difference is attributed to degradation. This calculation is summarized for TCE in Equation 1 in terms of percent degradation of the quantity of TCE in the seep water fed to the system.

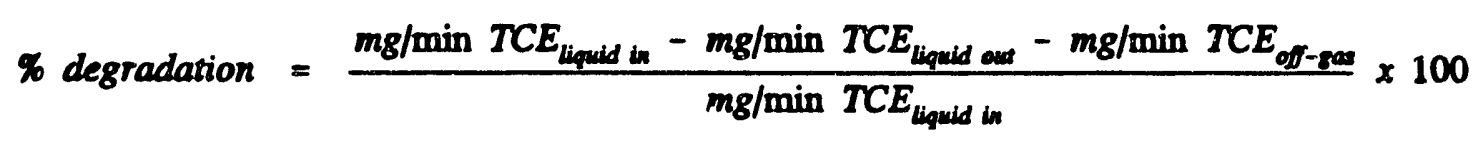

The degradations for the other compounds were obtained from similar calculations. The spreadsheet is saved on both floppy disk and the hard disk drive in the support lab every time it is updated, and it is backed up weekly on the hard disk drives in two nearby offices. 
Graphs of the data for each compound versus the date sampled are included in the spreadsheet and are easily updated to include new data.

\section{RESULTS}

\subsection{FALL 1991 OPERATING CAMPAIGN}

An overview of the major events associated with start-up and operation of the demonstration is given in Table 2. More details on daily events are shown in the comprehensive data tables in the Appendix A.

The system was inoculated with $2 \mathrm{~L}$ of dense microbial culture grown up from a mixed culture enriched from groundwater obtained from the DOE Kansas City Plant. ${ }^{3}$ Approximately $40 \mathrm{~L}$ of a liquid mineral salts medium was recirculated through both bioreactor

columns (designated $A$ and $B$ ) in series in total recycle at $1 \mathrm{~L} / \mathrm{min}$. A $3 \%$ methane/air mixture was fed to both columns in parallel at $0.5 \mathrm{~L} / \mathrm{min}$. This mode of operation was maintained for $\sim 1$ week to provide opportunity for development of biofilms on the packing in the columns. The $\mathrm{pH}$ was maintained at $\sim 7.0$ by manual addition of $\mathrm{HCl}$ as needed. Mineral nutrients were replenished periodically by removing a portion of the liquid (typically $10 \mathrm{~L}$ ) and replacing it with fresh medium (see Table 4).

On September 27, 1991, seven days after inoculation, seep water was first introduced to the system via the steam stripper for a limited period of $30 \mathrm{~min}$ at a feed rate of $1 \mathrm{~L} / \mathrm{min}$ of seep water. The overhead VOC-rich vapors were sent to the bioreactors, which were operated in total liquid recycle. Difficulties with the analytical procedures prevented monitoring of methane and organics at this time. Additional methods development work was carried out, and resumption of seep water treatment was initiated in early November using 
Table 4. Nutrients concentrate recipe"

\begin{tabular}{|c|c|}
\hline NUTRIENT & CONCENTRATION \\
\hline $\mathrm{CaCl}_{2} \cdot 2 \mathrm{H}_{2} \mathrm{O}$ & $1.325 \mathrm{~g} / \mathrm{L}$ \\
$\mathrm{MgSO}_{4} \cdot 7 \mathrm{H}_{2} \mathrm{O}$ & $5.0 \mathrm{~g} / \mathrm{L}$ \\
$\mathrm{KNO}_{3}$ & $5.0 \mathrm{~g} / \mathrm{L}$ \\
$\mathrm{FeCl}_{3}$ & $6.75 \mathrm{mg} / \mathrm{L}$ \\
$\mathrm{MnSO}_{4} \cdot \mathrm{H}_{2} \mathrm{O}$ & $0.05 \mathrm{mg} / \mathrm{L}$ \\
$\left.\mathrm{Zn}^{\mathrm{NO}}\right)_{2} \cdot 6 \mathrm{H}_{2} \mathrm{O}$ & $0.35 \mathrm{mg} / \mathrm{L}$ \\
$\mathrm{CoCl}_{2} \cdot \mathrm{H}_{2} \mathrm{O}$ & $0.05 \mathrm{mg} / \mathrm{L}$ \\
$\mathrm{MoO}_{3}$ & $0.05 \mathrm{mg} / \mathrm{L}$ \\
\hline
\end{tabular}

'This solution is added to the seep water feed at $\sim 5 \mathrm{~mL} / \mathrm{min}$. After dilution by the seep water, the concentrations in the feed to the bioreactors are $-1 \%$ of those listed in the table. These final concentrations correspond to $\sim 5 \%$ of the concentrations used in earlier laboratory tests. 
short operating periods as described previously. Following the addition of seep water, the methane consumption was monitored carefully for several hours to detect any adverse effects. This procedure was repeated on several occasions.

Addition of overhead vapors from the steam stripper to the bioreactors led to a significant decrease in methane consumption within an hour (see data in Appendix A). The original methane utilization rate was recovered slowly over several days. After several replications of this response, the steam stripper was operated alone (no seep water), and a comparable quantity of steam vapor was fed to the bioreactors. Again, the methane consumption dropped significantly, indicating that the behavior was caused by something other than the seep water.

Further investigation revealed that the steam fed to the stripper contained sufficient organics to create a film on a sample of the steam condensate and produce an odor. It was hypothesized that the source of these organics was the rubber lining of the new steam line installed to deliver steam to the process trailer from the plant steam supply at a nearby building. At this point, funding for the project was exhausted and operation of the bioreactor system was suspended. Solution of the steam supply problem was postponed until the second operating campaign in the spring/summer of 1992.

\subsection{SPRING/SUMMER 1992 OPERATING CAMPAIGN}

\section{Overview of Operating Campaign}

On March 5, 1992, following authorization to resume work, the bioreactors were reinoculated in a manner similar to the initial inoculation. Methane consumption was monitored frequently as an indicator of bioactivity (Appendix A). Methane consumption was 
observed to be quite dependent on temperature, which is expected for microbial metabolism. When the ambient temperature dropped to $<5^{\circ} \mathrm{C}$ overnight, the methane consumption observed in the morning was typically reduced by 20 to $40 \%$ compared to the methane consumption when the temperature was in the $25^{\circ} \mathrm{C}$ range late in the day. Shakedown of the air oxidation pretreatment equipment was completed, and analytical methods were refined for measuring the five target organics in liquid and gas samples.

On May 28, 1992, operation with seep water commenced with several short-term periods of 1 to $2 \mathrm{~h}$ at $1 \mathrm{~L} / \mathrm{min}$ of seep water and $0.5 \mathrm{~L} / \mathrm{min}$ of gas to each bioreactor column. (Liquid flow was sequential through the air oxidation unit and the two bioreactors in series. Gas flow was in parallel, with separate feed streams to each bioreactor column.) The addition of seep water caused no significant effect on methane consumption (Appendix A), so continuous operation was commenced at $0.5 \mathrm{~L} / \mathrm{min}$ of seep water. An additional $0.5 \mathrm{~L} / \mathrm{min}$ of liquid was recycled from the effluent of Column B back to the influent of Column A to provide a total liquid flow rate in the columns of $1 \mathrm{~L} / \mathrm{min}$ to assist in good liquid distribution across the packing at the top of each column.

Liquid and gas flow rates are shown in Fig. 9. After several weeks of operation in June, during which time samples were taken and analyzed (see following), the system was returned to total recycle when the waste tanker became full. Approximately 1 month was required to sample and analyze the contents of the tanker and obtain permission tc empty the tanker at the CNF. Treatment of seep water was resumed on August 3 in the air oxidation pretreatment mode and continued through September 1, at which time total recycle was again necessary while waiting for disposal of the contents of the waste tanker. 

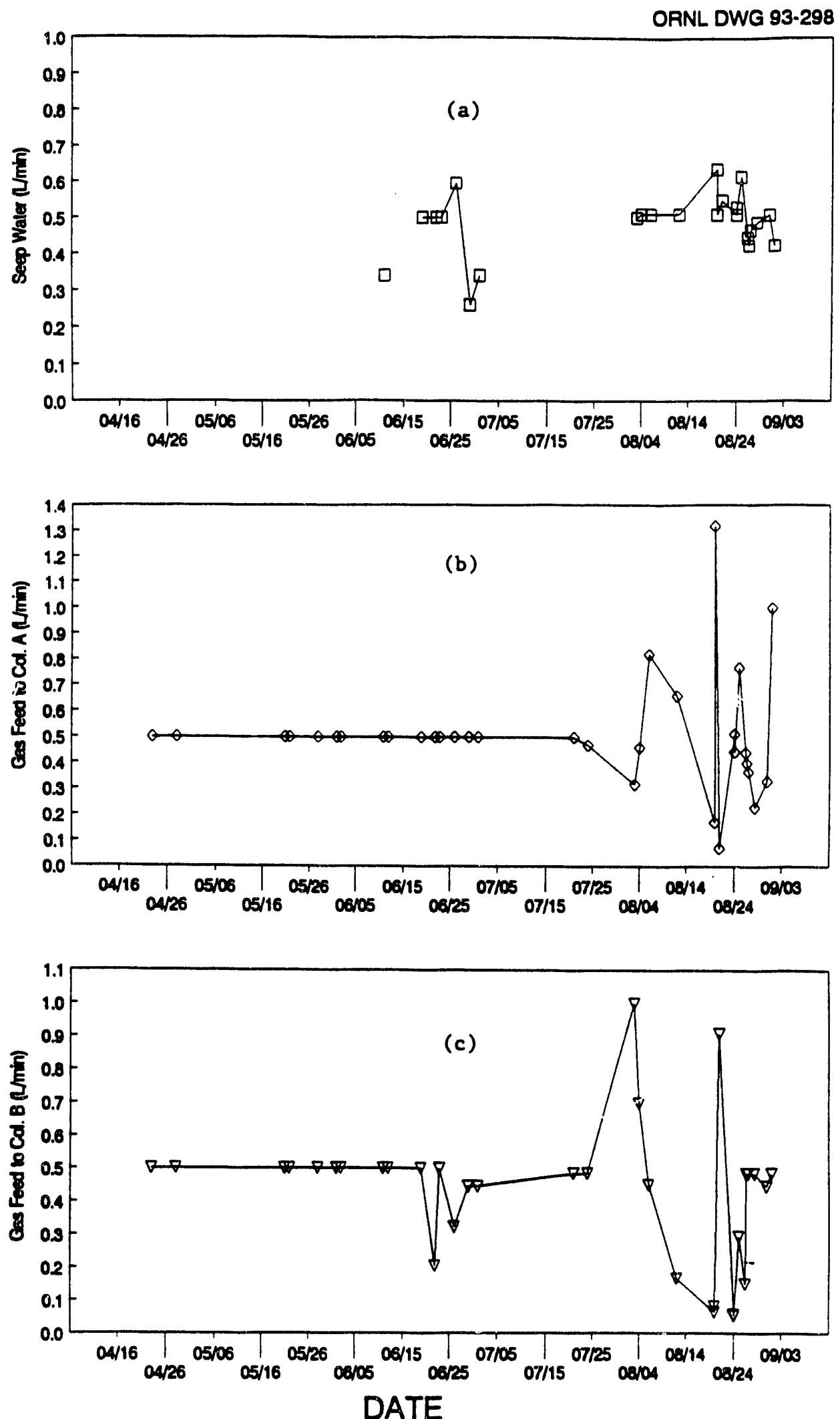

Fig. 9. Flow rates of (a) seep water to process; (b) methane/air to Column A; and (c) methane/air to Column B. 
On July 22, during operation in recycle, while waiting for waste disposal, TCE and 1,1,1-TCA were added to the bioreactors via a saturated aqueous solution in lieu of seep water. The purpose was to provide TCE to the system for degradation tests in the event that waste disposal was substantially delayed. TCA was added as a recalcitrant tracer. The saturated solution contained $\sim 1000 \mathrm{mg} / \mathrm{L}$ each of TCE and 1,1,1-TCA and was added to the bioreactors at $\sim 6 \mathrm{~mL} / \mathrm{min}$ for $\sim 18 \mathrm{~h}$. The experiment was repeated again on July 30 with a lower addition rate of $\sim 0.3 \mathrm{~mL} / \mathrm{min}$ and stopped on August 4 when treatment of seep water was resumed.

A variety of operational problems prevented maintenance of stable operating conditions for extended periods, with the exception of one good stable operating period for about 2 weeks at the end of August. An air leak in the line from the sump at the seep to the pump in the trailer caused the centrifugal feed pump to discharge at erratic flow rates and eventually lose its prime. The pump was replaced with a positive-displacement gear pump on July 1 , which has worked satisfactorily. Other difficulties included unsteady gas flow rates caused by fluctuating liquid levels in the bottom of the bioreactors and erratic gas addition to the air oxidation unit in the presence of back pressure from the liquid stream. The $\mathrm{pH}$ controller failed on August 10 and drove the $\mathrm{pH}$ up to 7.9 by unnecessary addition of base. This condition prevailed for several hours before the problem was discovered. The pH was monitored carefully for several days (it remained stable at 6.5 without addition of acid or base) until the controller was repaired.

\section{Methane Consumption}

Mass flow rates of methane to the bioreactors and in the off-gas are shown in Fig. 10. The uncertainty in the August data is estimated to be perhaps $\pm 25 \%$ due to difficulties in 

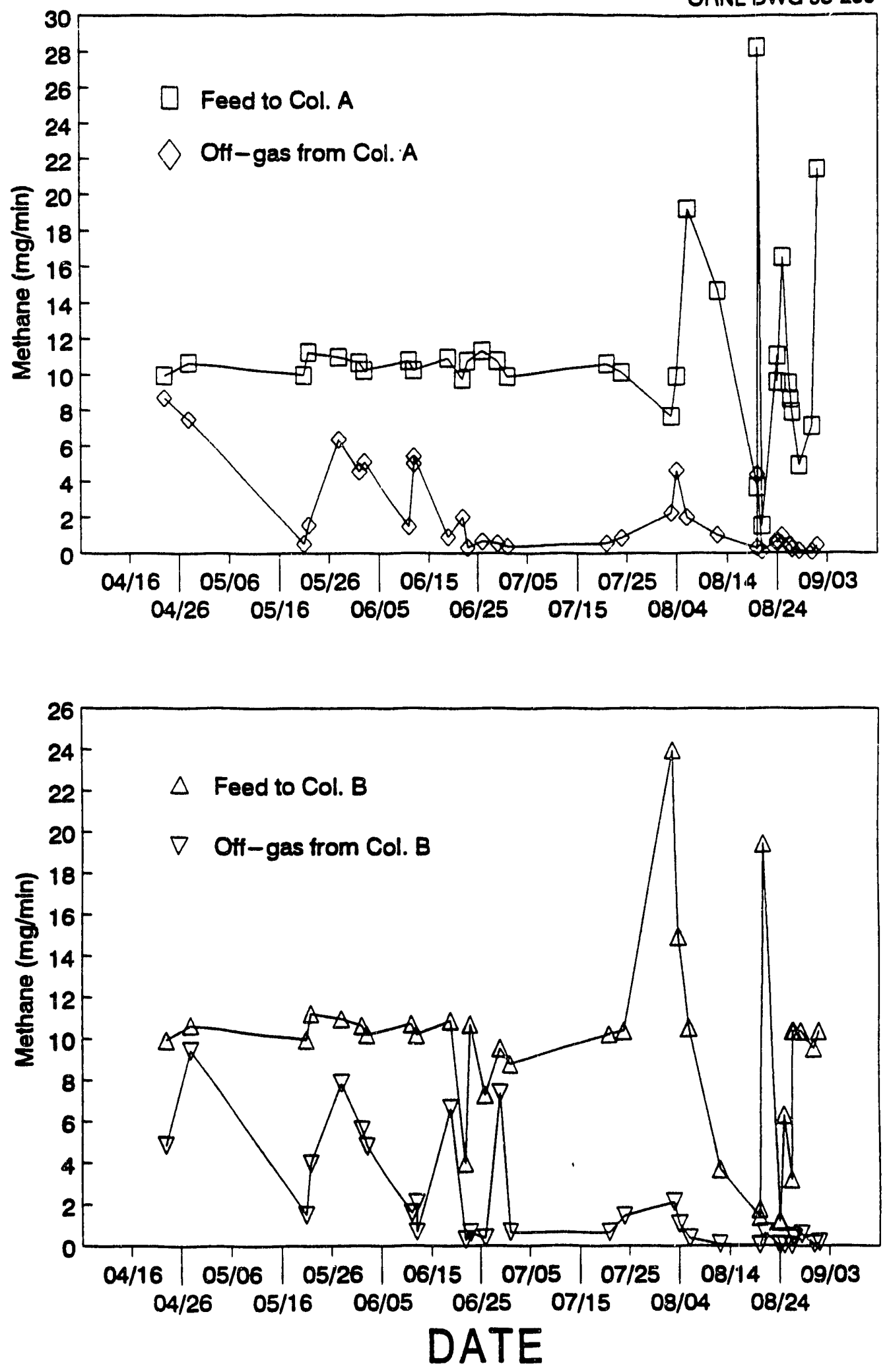

Fig. 10. Mass flow rates of methane into and out of process. 
maintaining a steady gas flow rate at times, as discussed previously. It can be seen that the methane consumption has been consistent and substantial, typically around $90 \%$ (see detailed data in Appendix A). Decreased methane consumption was observed to correlate with lower ambient temperatures, which is to be expected (data not shown). No adverse effect on methane consumption was observed when seep water was first fed to the system in the air oxidation pretreatment mode on May 28 and 29 anci again on August 3, 1992, when treatment of seep water was resumed after waste disposal.

\section{TCE Degradation}

Mass flow rates of TCE in the influent seep water and effluent liquid and off-gas streams are shown in Fig. 11. The TCE mass flow rate is the product of the concentration of TCE and the volumein flow rate for the various streams. Uncertainties in the mass flow rates are estimated to be about $\pm 10 \%$ for the liquid streams and perhaps $\pm 25 \%$ for the combinec' gas stream (columns A and B off-gas together) in August. Operating periods in June and Augusi are separated by the recycle period while awaiting discharge of the contents of the effluent tanker. No seep water was fed to the bioreactors during this latter period.

The mass flow data during the June time period suggest some degradation of TCE, as evidenced by lower TCE in the liquid effluent than in the feed and negligible TCE in the total combined off-gas. A quantitative measure of (apparent) degradation is derived from a steady-state material balance in which the difference between the TCE in and TCE ou: is defined to be degradation (see Eq. 1). Figure 12 shows the apparent TCE degradation determined in this manner, expressed in $\mu \mathrm{g} / \mathrm{min}$ (see Appendix A for daily percentages.). The TCE fed to the system is also shown for comparison. If the system is operating in a 


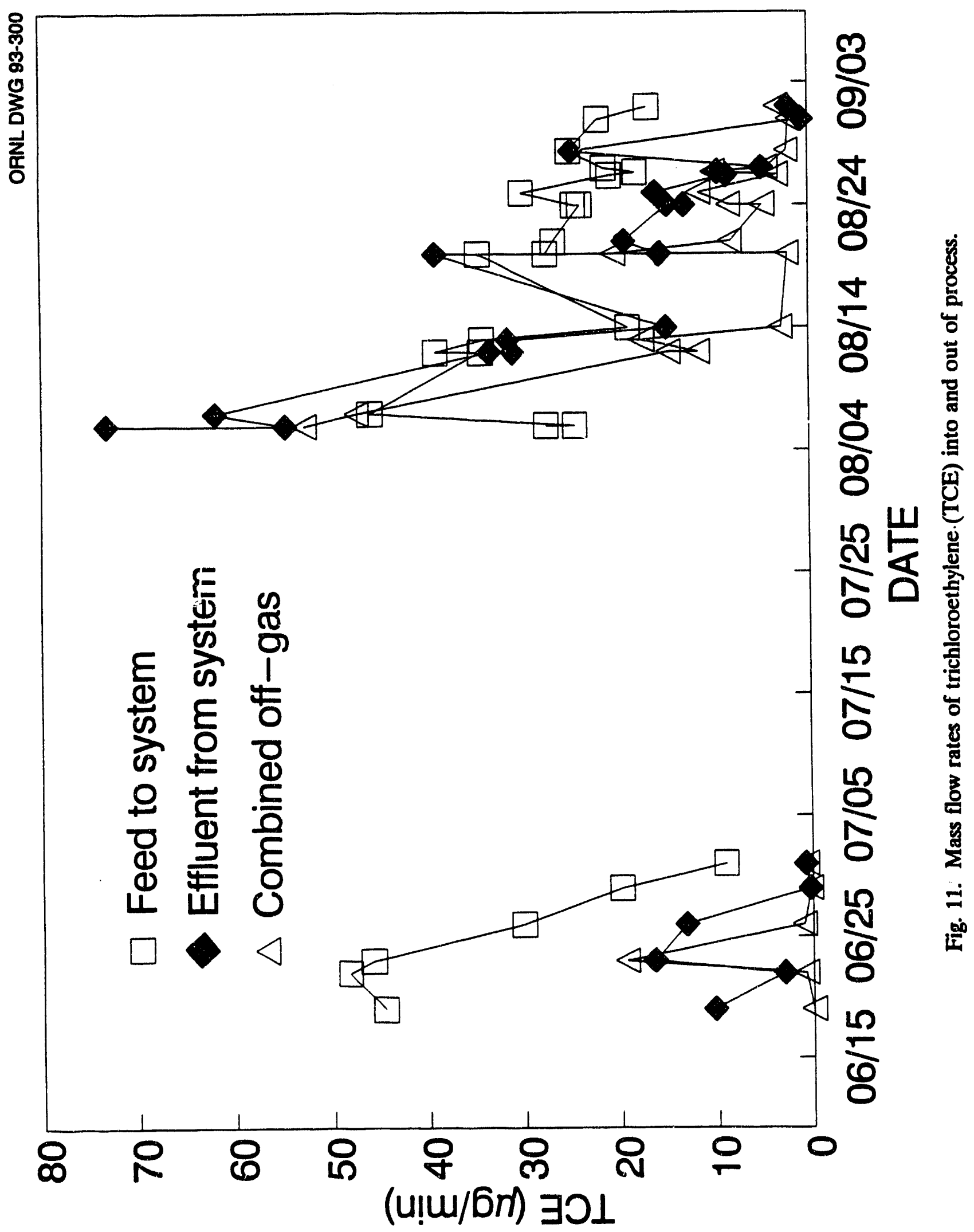




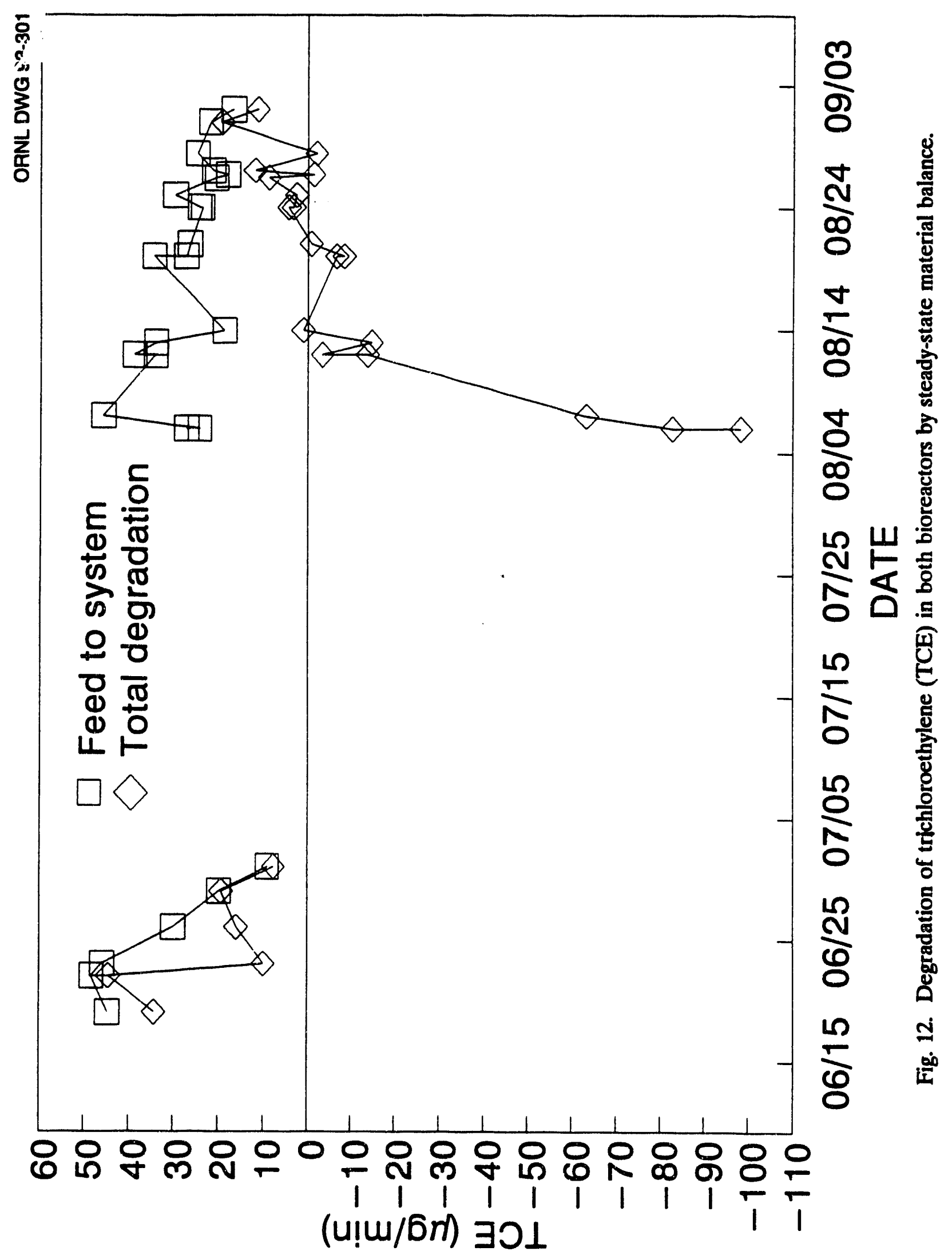


non-steady-state mode with accumulation or depletion of TCE in the system by means other than reaction (such as varying liquid and/or gas flow, varying inlet concentrations, adsorption/desorption), then the actual degradation of TCE is uncertain. The average liquid residence time in the system is $\sim 1.5 \mathrm{~h}$, which means that $\sim 6 \mathrm{~h}$ of stable operation is needed to achieve a steady-state from a hydraulic standpoint.

During June the data indicate $>50 \%$ degradation of TCE. However, during August the data indicate more TCE in the off-gas and liquid effluent than was fed to the bioreactors. This situation is probably a result of the experiment to introduce a step feed of TCE and 1,1,1-TCA to the bioreactors from July 30 to August 4, right before treatment of seep water was resumed. It is probable that an inventory of TCE accumulated in the bioreactors during this experiment (discussed following) and washed out when treatment of seep water resumed. Such accumulation and washout is consistent with the negative degradation rate observed in Fig. 12. (Similar but less dramatic behavior is seen for 1,1,1-TCA in Fig. 16.) The high values of TCE in both the liquid effluent and off-gas, compared to the values in June, support this hypothesis.

\subsubsection{Degradation of Other Organics}

Mass flow rates and calculated degradation rates for 1,1-DCA; 1,1,1-TCA; and PCE are shown in Figs. 13 through 18. The determination of biodegradation from these data is subject to the requirement for steady-state operation, just as for the TCE data. No methylene chloride or dichloroethylene (DCE) was detected in the seep water during this operating campaign [although previous analyses of the seep water (Table 1) indicated 0.3 $\mathrm{mg} / \mathrm{L}$ of methylene chloride and $0.7 \mathrm{mg} / \mathrm{L}$ of total $\mathrm{DCE}]$. 


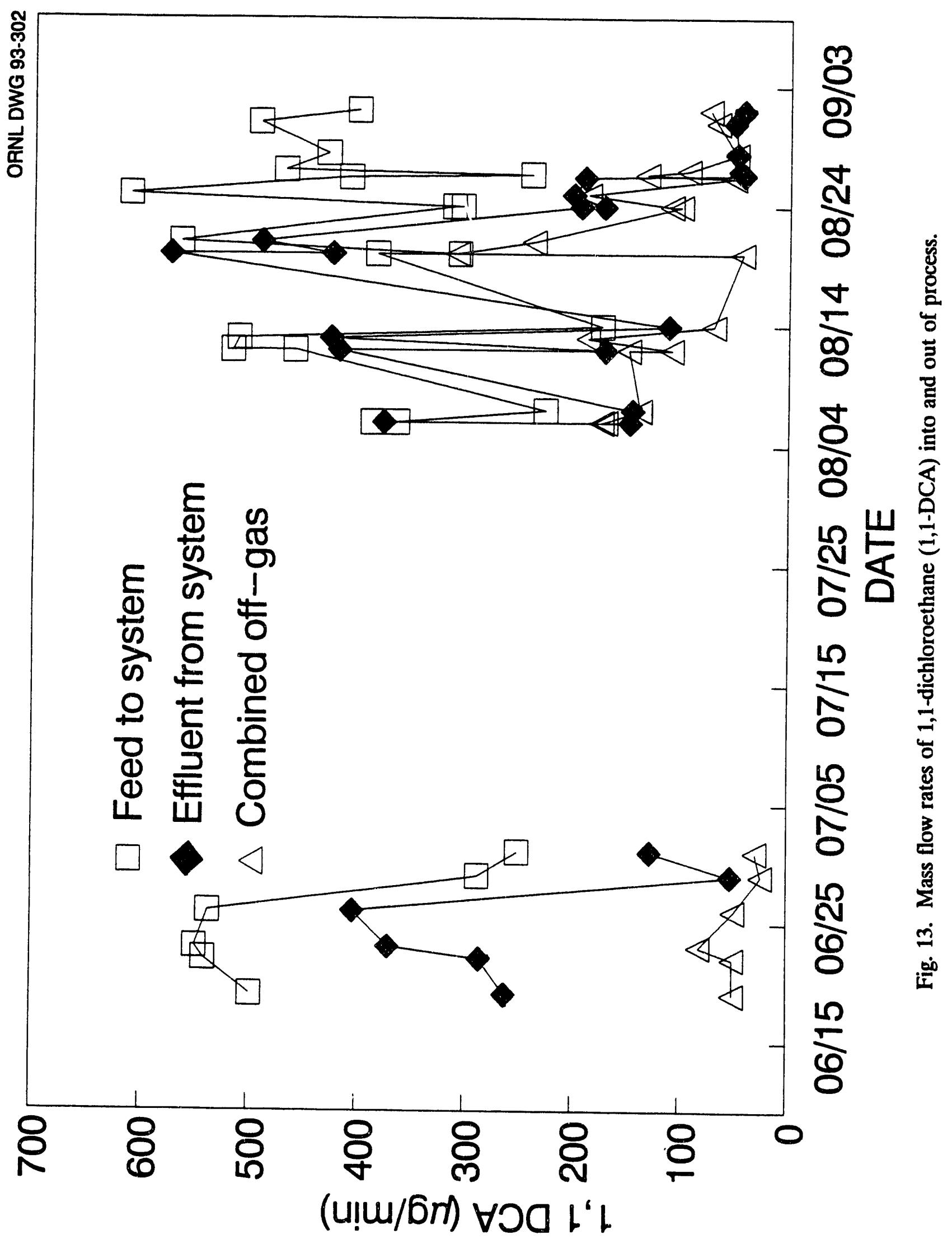




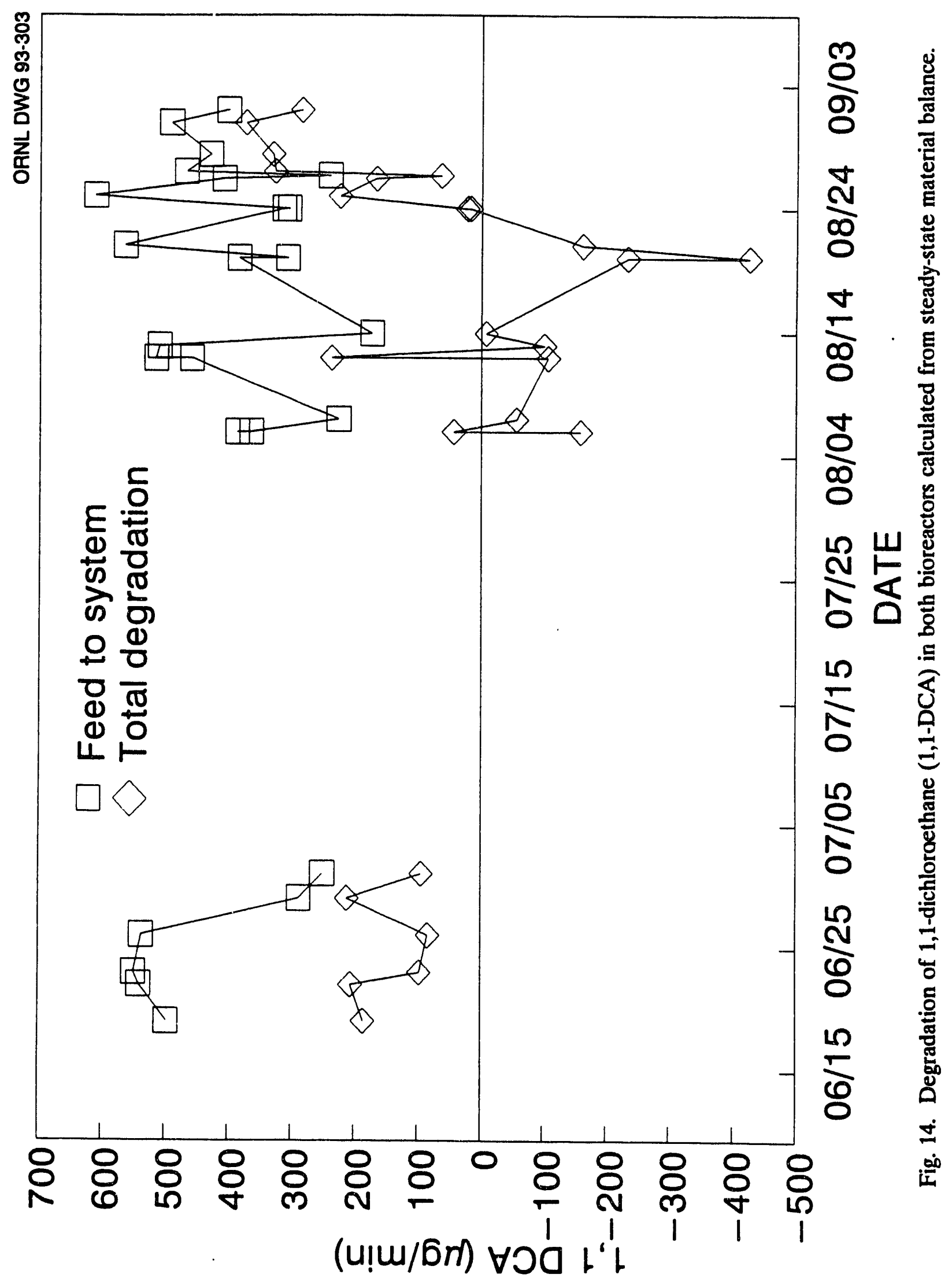




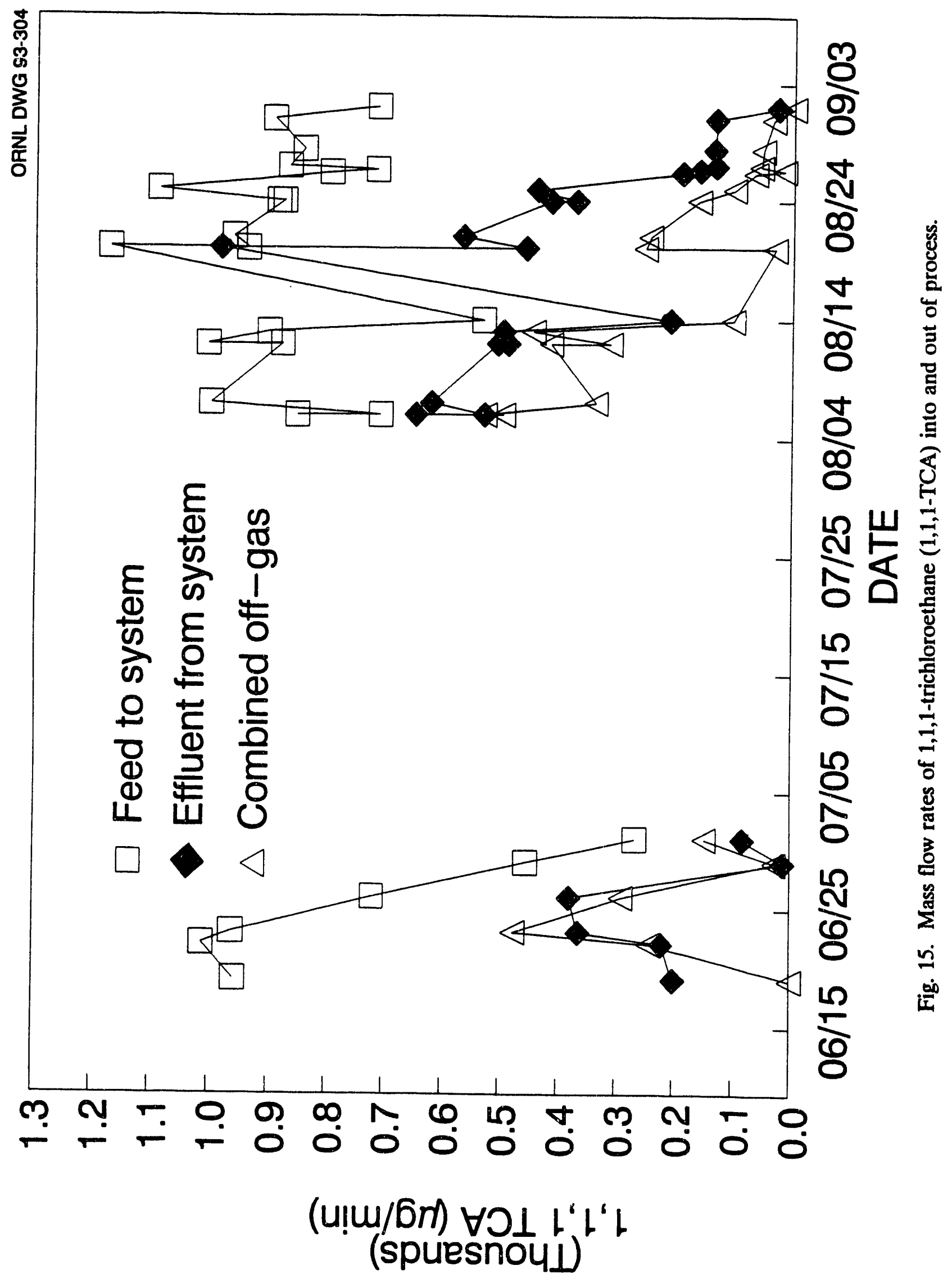




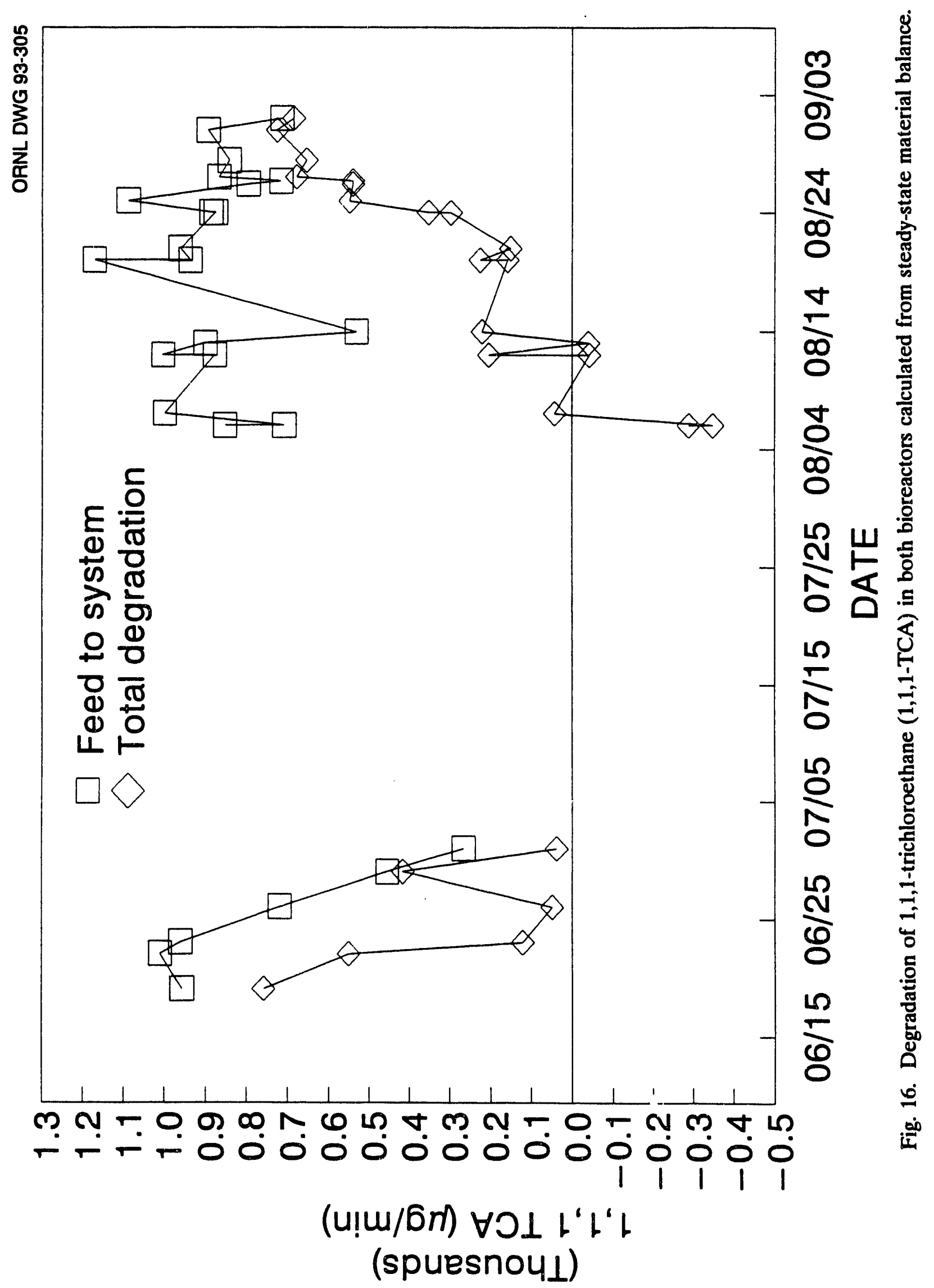




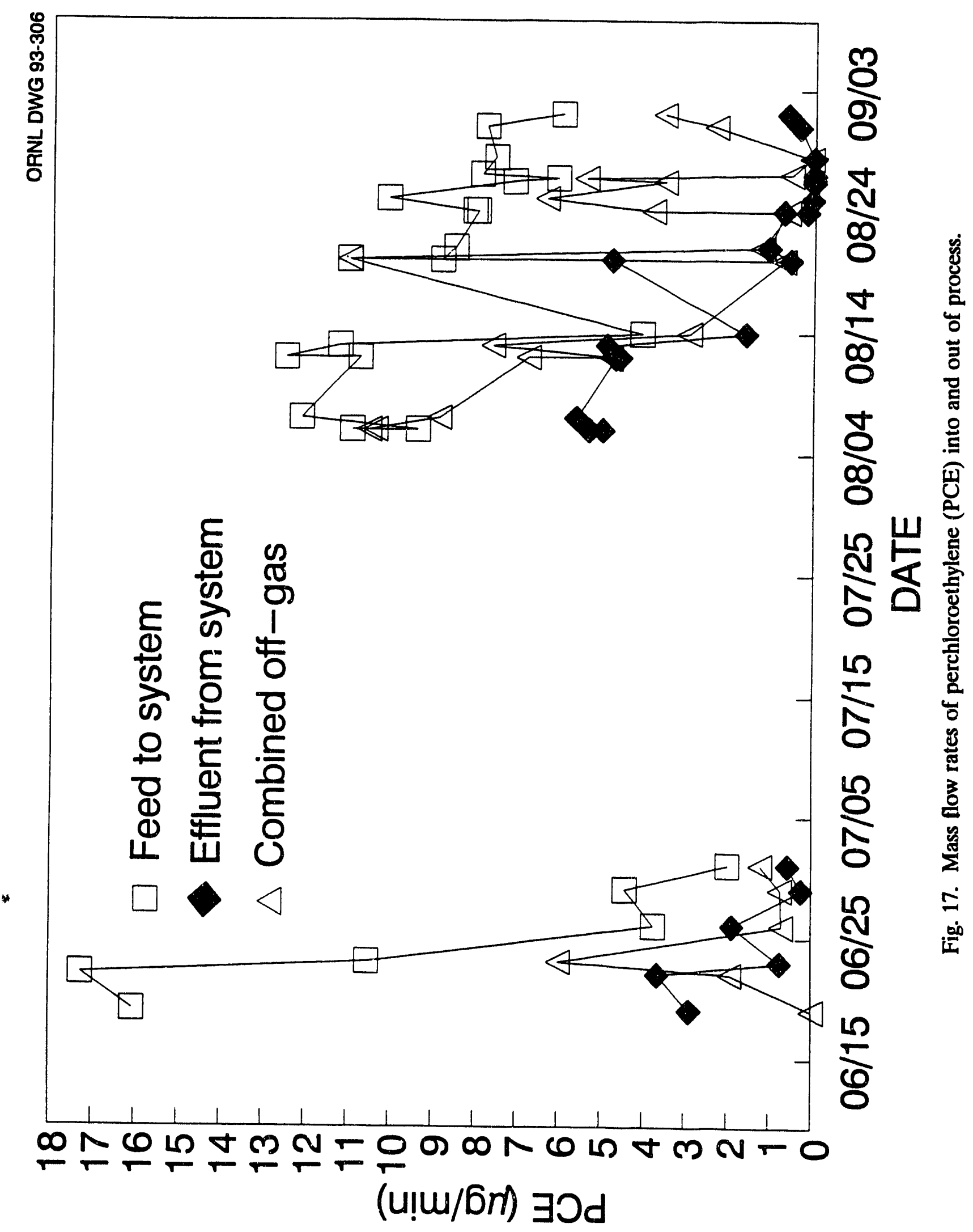




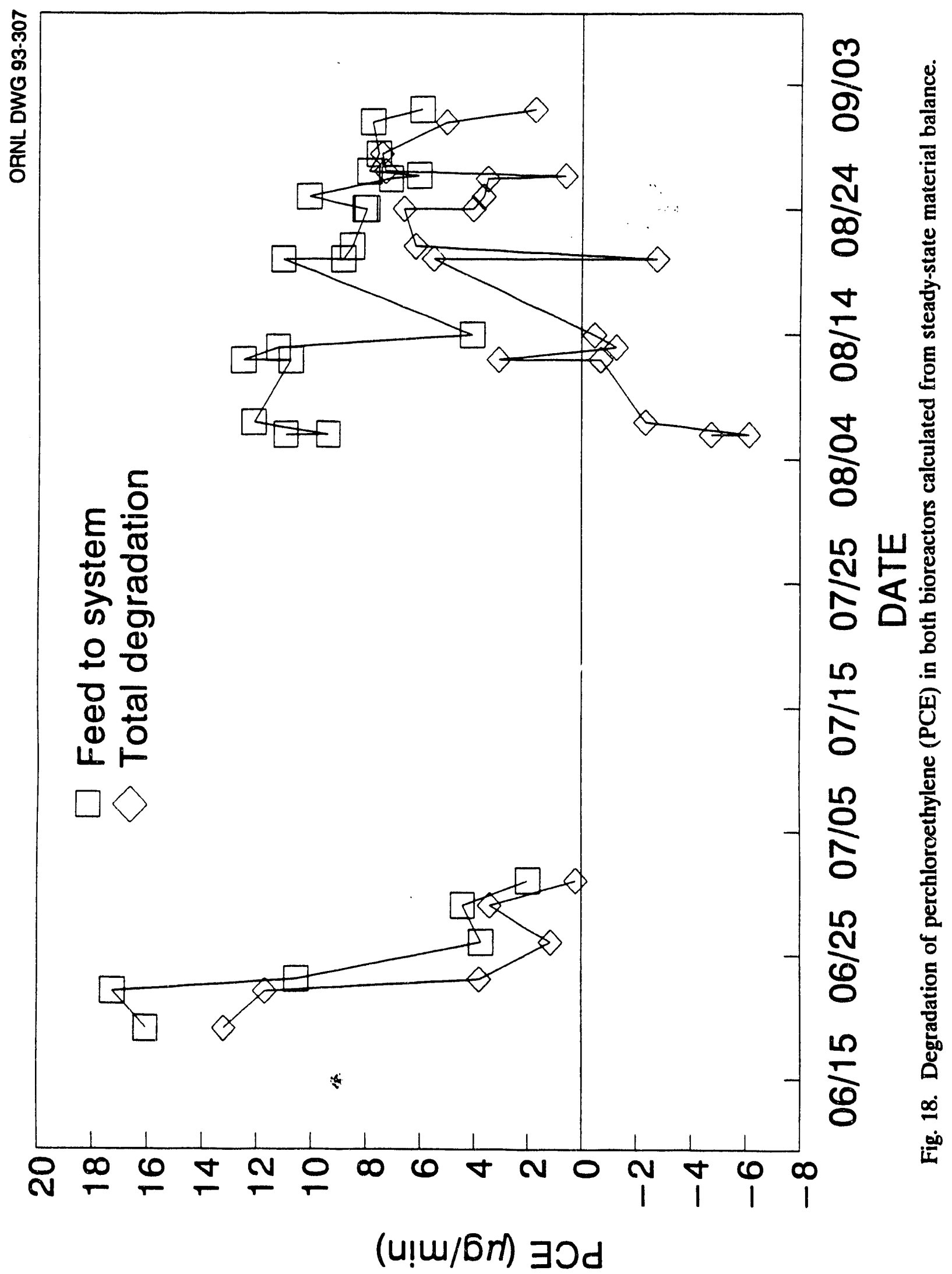


In general, the graphs show that the influents and effluents of the various organics often rise and fall together (but not always). This behavior suggests that common phenomena, such as varying influent concentrations and flow rates of seep water and gas streams, may be influencing all the constituents.

During the June operating period, apparent degradation of all VOCs was observed. The 1,1-DCA degradation was 20 to $30 \%$ (Fig. 14), the 1,1,1-TCA degradation was 10 to $80 \%$ (Fig. 16), and the PCE degradation was $>50 \%$ (Fig. 18). During the August operating period, the 1,1-DCA and PCE degradations varied widely and appeared to average $~ 0$ (Figs. 14 and 18). The 1,1,1-TCA degradation was negative in early August (washout from the earlier step feed) and then increased dramatically late in the month to $>90 \%$.

\section{Step Feed of Organics}

Approximately $5 \mathrm{~g}$ each of TCE and 1,1,1-TCA were added to the bioreactors on July 22 via a saturated aqueous solution during an 18 -h period while the system was on total recycle. This addition raised the measured concentrations of TCE and 1,1,1-TCA to $\sim 85$ $\mathrm{mg} / \mathrm{L}$ and $65 \mathrm{mg} / \mathrm{L}$, respectively, at which time the addition was discontinued. Methane analyses indicated no adverse effect on methane consumption (Appendix A). The experiment was repeated from July 30 through August 4 at a much lower addition rate but for a longer period. Approximately $2 \mathrm{~g}$ each of the two organics were added over this period. Assuming a limiting case of no biodegradation, the concentrations would rise to $\sim 50 \mathrm{mg} / \mathrm{L}$ in the $40 \mathrm{~L}$ of liquid in the bioreactors. However, some of the organics were undoubtedly lost in the offgas and probably adsorbed to solid phases. The maximum TCE and 1,1,1-TCA concentrations measured experimentally in the liquid phase were $-1.5 \mathrm{mg} / \mathrm{L}$ each on August 4 (See 
Appendix A). It is clear that this addition of TCE and 1,1,1-TCA was capable of creating the high effluent concentrations seen during early August.

Evidence of the step feed of TCE and 1,1,1-TCA in early August can be seen readily in Figs. 12 and 16 for TCE and 1,1,1-TCA, respectively. Both graphs show negative degradation rates in early August right after the step feed was stopped and treatment of seep water was resumed. This behavior is consistent with washout of the compounds. However, the PCE data (Fig. 18) show similar behavior, whereas no excess PCE was fed to the system. The off-gas rate was abnormally high at this time (see Fig. 9), which may have led to abnormally high volatilization rates for all VOCs. This unsteady-state behavior would depress the apparent degradation rates of all the VOCs.

\section{Statistical Evaluation}

The data exhibit a large amount of variability, which makes it difficult to determine if the system is at steady state and if the apparent degradation rates are significantly different from zero. The latter uncertainty was addressed statistically by comparing the apparent percent degradation of TCE; 1,1-DCA; and 1,1,1-TCA to the apparent percent degradation of PCE. In an aerobic environment, PCE is not believed to be biodegraded (however, see footnote to Table 5). At each time point, the apparent total percent degradation for PCE in both columns was subtracted from the percent degradation for the other three organics. A standard " $t$ " test was used to calculate a $95 \%$ confidence interval around the average of these differences for each column for the June and August operating periods. If the average of the differences falls outside the $95 \%$ confidence interval, then the average is considered to be significantly different from zero, which may indicate biodegradation (or other unsteadystate phenomena). 
Table 5. Statistical evaluation of the average differences between the apparent percent degradation of TCE; 1,1,1-TCA; and 1,1-DCA relative to the apparent percent degradation of PCE."

\begin{tabular}{|c|c|c|}
\hline COMPOUND & DATE & $\begin{array}{c}\text { PERCENT DIFFERENCE } \\
( \pm 95 \% \text { CONFIDENCE })\end{array}$ \\
\hline TCE & June & $20 \pm 23$ \\
& August & $-22 \pm 11$ \\
\hline $1,1-\mathrm{DCA}$ & June & $-14 \pm 16$ \\
& August & $-33 \pm 26$ \\
\hline $1,1,1-\mathrm{TCA}$ & June & $-8 \pm 11$ \\
& August & $-8 \pm 15$ \\
\hline
\end{tabular}

"If PCE degradation is hypothesized to be zero, then this analysis indicates if the target organics are degraded. Work by T. J. Phelps ${ }^{2}$ et al., University of Tennessee, suggests that PCE may be degraded in aerobic systems via anaerobic niches. If PCE is in fact being degraded, then this analysis indicates if target organics are degraded at percentages comparable to or greater than PCE. 
Table 5 shows a summary of the results of this statistical analysis. For the June operating period, the percents degradation of TCE; 1,1-DCA; and 1,1,1-TCA were not significantly different from the percent degradation of PCE. The early August period was omitted because of the washout from the step feed and the pH excursion on August 10. From August 12 through September 1, the percents degradation of TCE and 1,1-DCA were less than those of PCE, while 1,1,1-TCA was not significantly different. This analysis may be helpful in comparing the relative removals of the four VOCs but may not be definitive for degradation because it has not been established that the reference compound, PCE, is not degraded. Further statistical analyses will be carried out to evaluate the performance of the individual bioreactor columns.

\section{CONCLUSIONS}

Work to date during the start-up and initial operation of the cometabolic bioreactor process has indicated establishment of a stable biofilm population of methanotrophic microorganisms on the structured packing material in the columns. This conclusion is supported by significant consumption of methane over extended periods of time, including extended operation in once-through liquid flow that would wash unattached microbial cells from the system.

Satisfactory analytical methods have been developed and demonstrated for determination of TCE; 1,1-DCA; 1,1,1-TCA, and PCE in mixtures of these compounds at subppm levels in aqueous liquids and gases. These methods are working well for daily process monitoring.

Evidence for removal of TCE and other VOCs was seen in the June operating period and in late August, with apparently no sustained removal in early August. There are several explanations for the apparent lack of sustained degradation: 
1. Degradation may have been masked by the relatively large variability in the data and frequent unsteady-state conditions. Further operation of the system will lead to a larger data base from which to draw statistical inferences, and more operator experience should help to achieve more stable operation.

2. The apparent modest degradation seen in June may have been real, and subsequent degradation in August may have been inhibited by the pH excursion to 7.9 on August 10 (see Sect. 7.2.1). The data in late August appear to show some increase in degradation, which could be a recovery from the $\mathrm{pH}$ excursion. Modifications will he made to the system hardware to protect the microbial culture in the event of failure of the $\mathrm{pH}$ controller. Laboratory tests are under way with samples of the culture from the bioreactors to determine if the biological activity is still present. If not, the columns will be reinoculated before the next operational period to test the steam stripping pretreatment mode.

3. The liquid residence time may not have been long enough to achieve significant degradation at the ic concentrations in the seep water. If this is the case, then the steam stripping pretreatment mode is expected to produce much improved performance because the concentration of TCE and the other VOCs will be in the parts-per-million range in the bioreactors when the concentrated vapors from the steam stripper are fed to the bioreactors.

Performance of the cometabolic bioreactor process to date in the air oxidation mode has been consistent with realistic expectations for the normal mechanical and operational problems associated with the start-up of new experimental pilot-scale equipment. We anticipate that operation will become smoother and more routine, which will lead to more reliable data. With further acclimization of the microcrganisms, increased degradation of VOCs may be achieved.

\section{FUTURE ACTIVITIES}

The treatment of seep water was discontinued on September 1, 1992, and the bioreactor system was placed in total liquid recycle. No additions to the waste tanker were allowed after the contents were sampled on August 26 for comparison to the CNF waste acceptance criteria. Effluent generaced from August 26 through September 1 was contained 
in the 1500 -gal polyethylene tank and then transferred to the waste tanker after it was emptied. In FY 1993, the system will be operated in the steam stripper pretreatment mode. Further data analysis will be conducted to characterize the system performance for purposes of process evaluation and scaleup. The performance will be assessed in the context of comparison with earlier bench-scale development ${ }^{3}$ and conventional tools for reactor analysis.

\section{REFERENCES}

1. C. D. Little et al., "Trichloroethylene Biodegradation by Pure Cultures of a Methane-Oxidizing Bacterium," Appl. Environ. Microbiol. 54, $951-956$ (1988).

2. T. J. Phelps et al., "Biodegradation of Mixed-Organic Wastes by Microbial Consortia in Continuous-Recycle Expanded-Bed Bioreactors," Environ. Sci. Technol 25, 1461-1465 (1991).

3. T. L. Donaldson et al., Bench-Scale Process Development Studies for the Methanotrophic Technology: Co-Metabolic Bioreactor Demonstration at the Oak Ridge K-25 Site, ORNL/TM-12024 (August 1993).

4. G. W. Strandberg, T. L. Donaldson, and L. Farr, "Degradation of Trichloroethylene and Trans-1,2-dichloroethylene by a Methanotrophic Consortium in a Fixed-Film, Packed-Bed Bioreactor," Environ. Sci. Technol. 11, 1422-1425 (1989).

5. Test Plan: Cometabolic Bioreactor Demonstration at the Oak Ridge K-25 Site, Oak Ridge National Laboratory (Revision 1, April 1993). 


\section{APPENDIX A}

This appendix is a printout from the Lotus spreadsheet containing all the operating data and notes through September 1, 1992. 


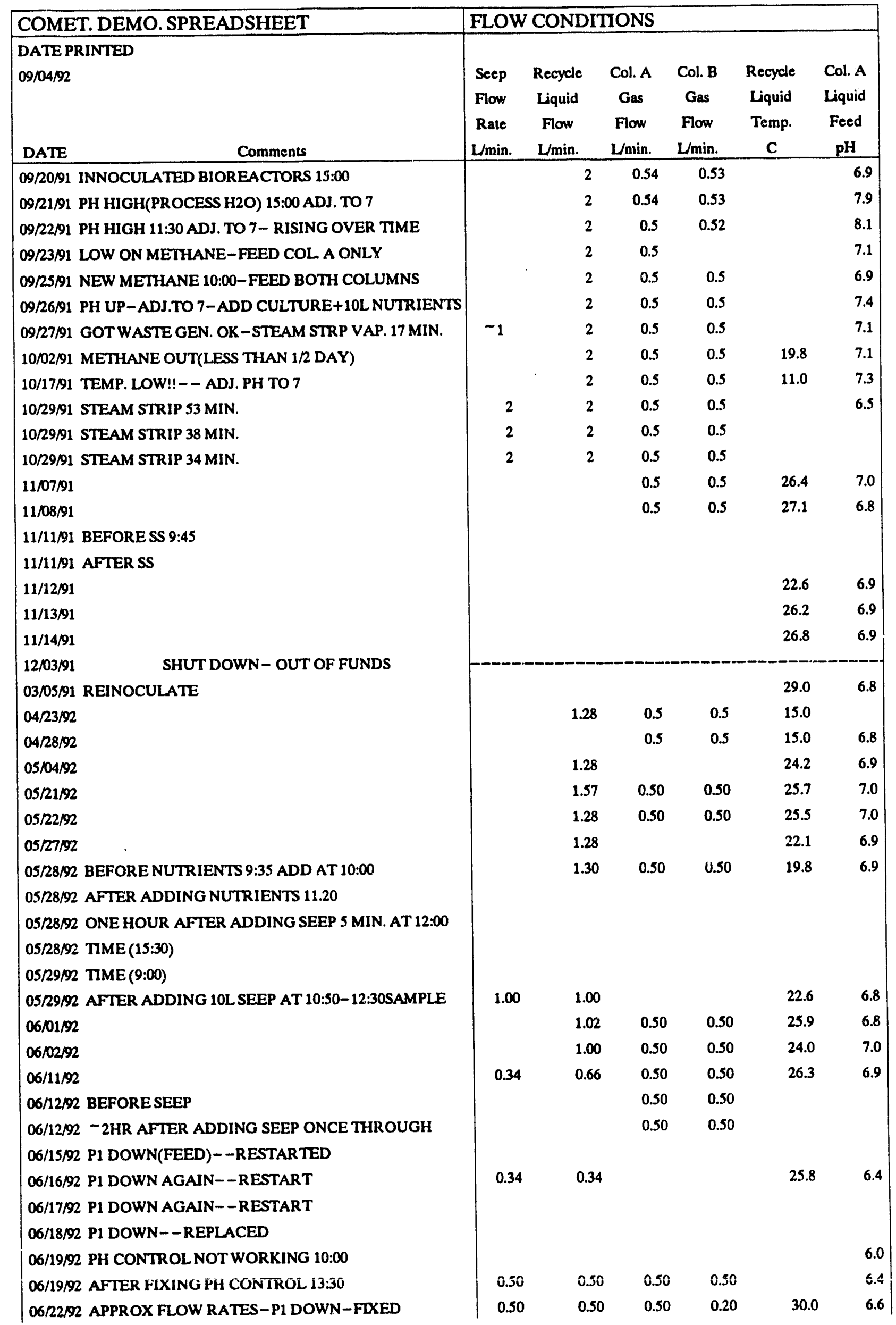




\begin{tabular}{|c|c|c|c|c|c|c|}
\hline \multirow{2}{*}{$\begin{array}{l}\text { COMET. DEMO. SPREADSHEET } \\
\text { DATE PRINTED } \\
09 / 04 / 92\end{array}$} & \multicolumn{6}{|c|}{ FLOW CONDITIONS } \\
\hline & $\begin{array}{l}\text { Seep } \\
\text { Flow } \\
\text { Rate } \\
\text { L/min. }\end{array}$ & $\begin{array}{l}\text { Recycle } \\
\text { Liquid } \\
\text { Flow } \\
\text { L/min. }\end{array}$ & $\begin{array}{l}\text { Col. A } \\
\text { Gas } \\
\text { Flow } \\
\text { L/min. }\end{array}$ & $\begin{array}{l}\text { Col. B } \\
\text { Gas } \\
\text { Flow } \\
\text { Lmin. }\end{array}$ & $\begin{array}{l}\text { Recycle } \\
\text { Liquid } \\
\text { Temp. } \\
\text { C } \\
\end{array}$ & $\begin{array}{l}\text { Col. A } \\
\text { Liquid } \\
\text { Feed } \\
\text { pH }\end{array}$ \\
\hline 06/23/92 APPROX FLOW RATES & 0.50 & 0.50 & 0.50 & 0.50 & & \\
\hline $\begin{array}{l}\text { 06/24/92 P1 LEAKING-REPLACED WITH OLD P1 } \\
\text { 06/25/92 PUMP DOWN-SYSTEM NOT OPERATING }\end{array}$ & 0.58 & 0.42 & & & 31.3 & 6.9 \\
\hline 06/26/92 WET TEST FOR GAS FLOWS & 0.60 & 0.57 & 0.50 & 0.32 & 26.6 & 6.9 \\
\hline $06 / 29 / 92$ & 0.26 & 0.80 & 0.50 & 0.45 & 26.0 & 7.1 \\
\hline 07/1/92 NEW GEAR PUMP FOR P1 & 0.34 & 0.60 & 0.50 & 0.45 & 27.1 & 6.8 \\
\hline 07/08/92 "WASTE FULL-RECYCLE ONLY & & & & & 27.5 & 7.1 \\
\hline $07 / 13 / 92$ & & & & 0.52 & & \\
\hline 07/21/92 & & 1.02 & 0.50 & 0.48 & 30.1 & $\mathbf{7 . 0}$ \\
\hline 07/22/92 * 6 HR AFTER ADDING TCE\&TCA STEP & & 0.50 & 0.50 & 0.48 & & \\
\hline 07/24/92 *STEP STOPPED & & & 0.47 & 0.48 & 29.8 & 7.0 \\
\hline 07/29/92 "RESTART STEP LOWER RATE & & 1.00 & & 0.48 & & 7.2 \\
\hline 07/30/92 * & & & & & & \\
\hline 07/31/92 "TANKER EMPTIED-AIR OX. DOWN & & & & 0.48 & 28.4 & 7.2 \\
\hline 08/03/92 STOP STEP-AIR OX. FIXED-START SEEP** & 0.50 & 0.25 & 0.32 & 1.00 & 30.4 & 6.8 \\
\hline 08/04/92 10:00 am TCE \& TCA LEFT FROM SPIKE?** & 0.51 & 0.26 & 0.46 & 0.70 & 24.0 & \\
\hline 08/04/92 $\quad \mathrm{PM}^{* *}$ & 0.51 & 0.26 & 0.42 & 0.61 & 32.2 & 6.9 \\
\hline $08 / 05 / 92$ & & & & & & \\
\hline $08 / 06 / 92$ & 0.51 & 0.26 & 0.82 & 0.45 & 23.5 & 6.6 \\
\hline 08/06/92 P.M.** & 0.51 & 0.26 & 0.61 & 0.82 & 24.8 & 6.7 \\
\hline 08/07/92 PH CONTROL NOT WORKING RIGHT** & 0.55 & 0.30 & 0.30 & 0.83 & 27.4 & 6.6 \\
\hline 08/11/92 PH UP TO 7.9 YESTERDAY CONTROLLER PROBLEM & & & & & & \\
\hline 08/12/92 A.M. NO PH CONTROL & 0.51 & 0.23 & 0.66 & 0.17 & 25.1 & 6.5 \\
\hline P.M. NO PH CONTROL** & 0.51 & 0.23 & 0.33 & 0.44 & 29.5 & 6.5 \\
\hline 08/13/92 P.M. NO PH CONTROL"* & 0.56 & 0.29 & 0.49 & 0.59 & 27.8 & 6.5 \\
\hline 08/14/92 A.M.NO PH CONTROL-•• & 0.34 & 0.30 & & 0.51 & 22.4 & 6.7 \\
\hline 08/20/92 A.M.I\&C PID PH CONTROLLER INSTALLED & 0.64 & 0.21 & 0.17 & 0.06 & 22.2 & 6.8 \\
\hline 08/20/92 P.M.PH CONTROL WORKS GOOD & 0.51 & 0.26 & 1.32 & 0.08 & 29.5 & 6.8 \\
\hline 08/21/92 SAND FILTER LEAK(POSSIBLE LOST GAS COLA)** & 0.55 & 0.30 & 0.07 & 0.91 & 29.0 & 6.8 \\
\hline A.M. LEAK FIXED & 0.51 & 0.23 & 0.51 & 0.06 & 25.0 & 6.7 \\
\hline 08/24/92 & 0.53 & 0.19 & 0.44 & 0.05 & 28.4 & 6.7 \\
\hline 08/25/92 & 0.62 & 0.23 & 0.77 & 0.29 & 28.4 & 6.7 \\
\hline $08 / 26 / 92$ & 0.45 & 0.36 & 0.44 & 0.15 & 26.8 & 6.7 \\
\hline $08 / 26 / 92$ & 0.43 & 0.34 & 0.40 & 0.48 & 30.8 & 7.0 \\
\hline $08 / 27 / 92$ & 0.47 & 0.34 & 0.37 & 0.48 & 26.0 & 7.0 \\
\hline $08 / 28,92$ & 0.49 & 0.34 & 0.23 & 0.48 & 24.8 & 6.8 \\
\hline $08 / 31 / 92$ & 0.51 & 0.40 & 0.33 & 0.45 & 22.2 & 6.8 \\
\hline $09 / 01 / 92$ & 0.43 & 0.43 & 1.00 & 0.48 & 24.2 & 7.1 \\
\hline
\end{tabular}




\begin{tabular}{|c|c|c|c|c|c|}
\hline & \multicolumn{5}{|c|}{ METHANE CONCENTRATIONS } \\
\hline $\begin{array}{l}\text { DATE PRINTED } \\
09 / 04 / 92\end{array}$ & $\begin{array}{l}\text { Inlet } \\
\text { G1 } \\
\% \\
\end{array}$ & $\begin{array}{c}\text { Col. A } \\
\text { Emluent } \\
\text { G2 } \\
\% \\
\end{array}$ & $\begin{array}{c}\text { Col. A } \\
\text { Percent } \\
\text { Used } \\
\% \\
\end{array}$ & $\begin{array}{c}\text { Col. B } \\
\text { Effuent } \\
\text { G3 } \\
\% \\
\end{array}$ & $\begin{array}{c}\text { Col. B } \\
\text { Percent } \\
\text { Used } \\
\% \\
\end{array}$ \\
\hline $11 / 07 / 91$ & 2.95 & 1.06 & 64.18 & 1.16 & 60.56 \\
\hline 11/08/91 & 2.90 & 1.39 & 52.17 & 1.54 & 46.83 \\
\hline 11/11/91 BEFORE SS 9:45 & 2.85 & 0.86 & 69.91 & 0.98 & 65.48 \\
\hline 11/11/91 AFTER SS & 3.02 & 2.45 & 18.89 & 2.40 & 20.48 \\
\hline $11 / 12 / 91$ & 3.08 & 2.22 & 28.11 & 3.08 & 0.00 \\
\hline $11 / 13 / 91$ & 2.88 & 1.96 & 31.83 & 2.10 & 27.00 \\
\hline $11 / 14 / 91$ & 2.61 & 1.70 & 34.92 & 1.58 & 39.56 \\
\hline $\begin{array}{l}\text { 12/03/91 SHUT DOWN- OUT OF FUNDS } \\
\text { 03/05/91 REINOCULATE }\end{array}$ & & & & & \\
\hline $04 / 23 / 92$ & 2.79 & 2.43 & 12.68 & 1.36 & 51.24 \\
\hline 04/28/92 & 2.98 & 2.09 & 29.93 & 2.65 & 11.36 \\
\hline $05 / 04 / 92$ & 3.12 & 0.83 & 73.52 & 1.35 & 56.82 \\
\hline $05 / 21 / 92$ & 2.79 & 0.15 & 94.76 & 0.42 & 85.11 \\
\hline 05/22/92 & 3.15 & 0.44 & 86.07 & 1.11 & 64.77 \\
\hline $05 / 27 / 92$ & 2.93 & 2.25 & 23.20 & 2.55 & 12.93 \\
\hline 05/28/92 BEFORE NUTRIENTS 9:35 ADD AT 10:00 & 3.07 & 1.77 & 42.34 & 2.20 & 28.44 \\
\hline 05/28/92 AFTER ADDING NUTRIENTS 11.20 & 3.07 & 1.52 & 50.54 & 2.10 & 31.73 \\
\hline 05/28/92 ONE HOUR AFTER ADDING SEEP 5 MIN. AT 12:00 & 3.07 & 1.49 & 51.64 & 1.91 & 37.91 \\
\hline 05/28/92 TIME (15:30) & 3.07 & 1.30 & 57.57 & 1.81 & 41.10 \\
\hline 05/29/92 TIME (9:00) & 2.98 & 0.71 & 76.19 & 0.99 & 66.80 \\
\hline 05/29/92 AFTER ADDING 10L SEEP AT 10:50-12:30SAMPLE & 2.98 & 0.69 & 76.93 & 0.89 & 70.15 \\
\hline $06 / 01 / 92$ & 2.98 & 1.27 & 57.45 & 1.56 & 47.52 \\
\hline 06/02/92 & 2.86 & 1.42 & 50.24 & 1.34 & 53.11 \\
\hline $06 / 11 / 92$ & 3.00 & 0.41 & 86.30 & 0.44 & 85.50 \\
\hline 06/12/92 BEFORE SEEP & 2.85 & 1.39 & 51.16 & 0.57 & 79.87 \\
\hline 06/12/92 2HR AFTER ADDING SEEP ONCE THROUGH & 2.85 & 1.50 & 47.27 & 0.18 & 93.72 \\
\hline C6/15/92 P1 DOWN(FEED)--RESTARTED & 2.79 & 2.22 & 20.55 & 0.42 & 85.11 \\
\hline 06/16/92 P1 DOWN AGAIN--RESTART & 3.00 & 2.49 & 16.98 & 0.36 & 88.17 \\
\hline 06/17/92 P1 DOWN AGAIN--RESTART & 3.13 & 2.59 & 17.09 & 0.47 & 85.06 \\
\hline 06/18/92 P1 DOWN--REPLACED & 3.05 & 1.11 & 63.56 & 0.70 & 77.10 \\
\hline 06/19/92 PH CONTROL NOT WORKING 10:00 & 3.05 & 1.53 & 49.87 & 1.91 & 37.48 \\
\hline 06/19/92 AFTER FIXING PH CONTROL 13:30 & 3.05 & 0.25 & 91.77 & 1.86 & 39.16 \\
\hline 06/22/92 APPROX FLOW RATES-P1 DOWN-FDXED & 2.72 & 0.56 & 79.34 & 0.19 & 93.15 \\
\hline 06/23/92 APPROX FLOW RATES & 3.00 & 0.08 & 97.20 & 0.18 & 94.17 \\
\hline 06/24/92 P1 LEAKING-REPLACED WITH OLD P1 & & & ERR & & ERR \\
\hline 06/25/92 PUMP DOWN-SYSTEM NOT OPERATING & 3.18 & 0.11 & 96.54 & 0.10 & 96.92 \\
\hline 06/26/92 WET TEST FOR GAS FLOWS & 3.16 & 0.18 & 94.21 & 0.16 & 95.09 \\
\hline $06 / 29 / 92$ & 3.00 & 0.15 & 95.07 & 2.32 & 22.77 \\
\hline 07/01/92 NEW GEAR PUMP FOR P1 & 2.76 & 0.10 & 96.27 & 0.20 & 92.61 \\
\hline 07/08/92 'WASTE FULL-RECYCLE ONLX & 2.75 & 0.31 & 88.89 & 0.29 & 89.33 \\
\hline $07 / 13 / 92$ & 2.82 & 0.08 & 97.20 & 0.18 & 93.72 \\
\hline $0721 / 92$ & 2.96 & 0.16 & 94.63 & 0.19 & 93.65 \\
\hline 07/22/92 -6 HR AFTER ADDING TCE\&TCA STEP & & & ERR & & ERR \\
\hline 07/24/92 "STEP STOPPED & 3.00 & 0.25 & 91.60 & 0.42 & 86.17 \\
\hline 07/29/92 "RESTART STEP LOWER RATE & 5.17 & 0.12 & 97.75 & 0.27 & 94.79 \\
\hline
\end{tabular}


54

\begin{tabular}{|c|c|c|c|c|c|}
\hline $\begin{array}{l}\text { COMET. DEMO. SPREADSHEET } \\
\text { DATE PRINTED } \\
09 / 04 / 92\end{array}$ & \multicolumn{5}{|c|}{ METHANE CONCENTRATIONS } \\
\hline $\begin{array}{l}\text { DATE PRINTED } \\
09 / 04 / 92\end{array}$ & $\begin{array}{l}\text { Inlet } \\
\text { G1 } \\
\%\end{array}$ & $\begin{array}{l}\text { Col. A } \\
\text { Efluent } \\
\text { G2 } \\
\%\end{array}$ & $\begin{array}{l}\text { Col. A } \\
\text { Percent } \\
\text { Used } \\
\%\end{array}$ & $\begin{array}{c}\text { Col. B } \\
\text { Effluent } \\
\text { G3 } \\
\%\end{array}$ & $\begin{array}{l}\text { Col. B } \\
\text { Percent } \\
\text { Used } \\
\%\end{array}$ \\
\hline $07 / 30 / 92$ & 5.17 & 0.12 & 97.70 & 0.26 & 94.97 \\
\hline 07/31/92 •TANKER EMPTIED-AIR OX. DOWN & 3.00 & 0.10 & 96.57 & 0.15 & 95.00 \\
\hline 08/03/92 STOP STEP-AIR OX. FIXED-START SEEP** & 3.36 & 0.99 & 70.46 & 0.30 & 91.16 \\
\hline 08/04/92 10:00 am TCE \& TCA LEFT FROM SPIKE?** & 3.00 & 1.40 & 53.30 & 0.21 & 92.97 \\
\hline 08/04/92 $\quad$ PM** & & & ERR & & ERR \\
\hline 08/05/92 & 3.03 & 1.35 & 55.61 & 0.31 & 89.83 \\
\hline 08/06/92 & 3.28 & 0.34 & 89.63 & 0.11 & 96.65 \\
\hline 08/06/92 & & & ERR & & ERR \\
\hline 08/07/92 PH CONTROL NOT WORKING RIGHT** & & & ERR & & ERR \\
\hline 08/11/92 PH UP TO 7.9 YESTERDAY CONTROLLER PROBLEM & & & ERR & & ERR \\
\hline $08 / 12 / 92 \quad$ A.M. NO PH CONTROL & 3.11 & 0.22 & 93.09 & 0.06 & 97.97 \\
\hline P.M. NO PH CONTROL** & & & ERR & & ERR \\
\hline P.M. NO PH CONTROL** & & & ERR & & ERR \\
\hline 08/14/92 A.M.NO PH CONTROL- $\cdot *$ & 2.26 & 0.08 & 96.63 & 0.06 & 97.56 \\
\hline 08/20/92 A.M.I\&C PID PH CONTROLIER INSTALLED & 3.00 & 0.24 & 92.13 & 0.03 & 98.93 \\
\hline 08/20/92 P.M.PH CONTROL WORKS GOOD & 3.00 & 0.46 & 84.67 & 0.01 & 99.73 \\
\hline 08/21/92 SAND FILTER LEAK(POSSIBLE LOST GAS COLA)** & 3.00 & 0.17 & 94.25 & 0.10 & 96.79 \\
\hline 08/24/92 A.M. LEAK FIXED & 3.00 & 0.19 & 93.80 & 0.01 & 99.67 \\
\hline 08/24/92 & 3.00 & 0.18 & 94.17 & 0.05 & 98.37 \\
\hline $08 / 25 / 92$ & 3.00 & 0.17 & 94.23 & 0.01 & 99.67 \\
\hline $08 / 26 / 92$ & 3.00 & 0.14 & 95.33 & 0.01 & 99.83 \\
\hline $08 / 26 / 92$ & 3.00 & 0.15 & 95.08 & 0.12 & 95.91 \\
\hline $08 / 27 / 92$ & 3.00 & 0.08 & 97.27 & 0.10 & 96.67 \\
\hline $08 / 28 / 92$ & 3.00 & 0.08 & 97.35 & 0.16 & 94.67 \\
\hline $08 / 31 / 92$ & 3.00 & 0.03 & 99.13 & 0.02 & 99.27 \\
\hline $09 / 01 / 92$ & 3.00 & 0.06 & 98.00 & 0.04 & 98.60 \\
\hline
\end{tabular}




\begin{tabular}{|c|c|c|c|c|c|c|c|c|}
\hline \multirow{2}{*}{$\begin{array}{l}\text { COMET. DEMO. SPREADSHEET } \\
\text { DATE PRINTED } \\
09 / 04 / 92\end{array}$} & \multicolumn{8}{|c|}{ TCE CONCENTRATIONS } \\
\hline & $\begin{array}{c}\text { Inlet } \\
\mathrm{LI} \\
\mu \mathrm{g} / \mathrm{L}\end{array}$ & $\begin{array}{c}\text { Col. A } \\
\text { Effluent } \\
\text { L3 } \\
\mu \mathrm{g} / \mathrm{L} \\
\end{array}$ & $\begin{array}{c}\text { Col. B } \\
\text { Effluent } \\
\text { LA } \\
\mu \mathrm{g} / \mathrm{L}\end{array}$ & $\begin{array}{c}\text { Col. A } \\
\text { Off-Gas } \\
\text { G2 } \\
\mu g / L \\
\end{array}$ & $\begin{array}{c}\text { Col. B } \\
\text { Off-Gas } \\
\text { G2 } \\
\mu \mathrm{g} / \mathrm{L}\end{array}$ & $\begin{array}{c}\text { Col. A } \\
\text { Percent } \\
\text { Deg. } \\
\% \\
\end{array}$ & $\begin{array}{c}\text { Col. B } \\
\text { Percent } \\
\text { Deg. } \\
\%\end{array}$ & $\begin{array}{c}\text { Overall } \\
\text { Degraded } \\
\%\end{array}$ \\
\hline 06/19/92 AFTER FIXING PH CONTROL 13:30 & 89.22 & 102.69 & 20.63 & & & -86.97 & 79.91 & 76.88 \\
\hline 06/22/92 APPROX FLOW RATES-P1 DOWN-FIXED & 96.47 & 50.00 & 6.01 & 1.09 & 0.99 & 1.35 & 87.58 & 92.22 \\
\hline 06/23/92 APPROX FLOW RATES & 91.65 & 44.61 & 32.99 & 16.69 & 16.00 & 10.18 & 8.11 & 21.74 \\
\hline $\begin{array}{l}\text { 06/24/92 P1 LEAKING-REPLACED WITH OLD P1 } \\
\text { 06/25/92 PUMP DOWN-SYSTEM NOT OPERATING }\end{array}$ & 87.60 & 35.32 & 21.45 & & & & & \\
\hline 06/26/92 WET TEST FOR GAS FLOWS & 50.52 & 29.41 & 22.10 & 1.07 & 1.16 & 18.24 & 23.78 & $\$ 3.16$ \\
\hline $06 / 29 / 92$ & 76.30 & 1.60 & 1.00 & 0.32 & 0.15 & 91.03 & 33.51 & 97.55 \\
\hline $\begin{array}{l}\text { 07/01/92 NEW GEAR PUMP FOR P1 } \\
07 / 08 / 92 \cdot \text { WASTE FULL-RECYCLE ONLY } \\
07 / 13 / 92 \\
07 / 21 / 92\end{array}$ & 26.61 & 2.38 & 2.13 & 0.86 & 0.53 & 74.19 & -0.12 & 84.63 \\
\hline $\begin{array}{l}\text { 07/22/92 * } 6 \text { HR AFTER ADDING TCE\&TCA STEP } \\
\text { 07/24/92 *STEP STOPPED } \\
07 / 29 / 92 \text { "RESTART STEP LOWER RATE } \\
07 / 30 / 92 \text { * } \\
\text { 07/31/92 "TANKER EMPTIED-AIR OX. DOWN } \\
\text { 08/03/92 STOP STEP-AIR OX. FIXED-START SEEP*" }\end{array}$ & 749.87 & 464.52 & 247.79 & 264.83 & 122.55 & -381.80 & 33.99 & ERR \\
\hline 08/04/92 10:00 am TCE \& TCA LEFT FROM SPIKE?** & & 1256.66 & 1526.55 & 592.09 & 597.98 & -212.42 & -64.61 & ERR \\
\hline 08/04/92 $\quad P M * *$ & 472.31 & 887.81 & 590.24 & 505.98 & 212.48 & -126.61 & 14.50 & -166.13 \\
\hline 08/05/92 & & & & & & & -59.23 & -359.75 \\
\hline $\begin{array}{l}\text { A.M.** } \\
\text { P.M.** }\end{array}$ & $\begin{array}{l}53.64 \\
47.78\end{array}$ & $\begin{array}{r}107.74 \\
80.87\end{array}$ & $\begin{array}{l}143.53 \\
107.11\end{array}$ & $\begin{array}{l}37.80 \\
36.10\end{array}$ & $\begin{array}{l}47.94 \\
35.85\end{array}$ & $\begin{array}{l}-76.19 \\
-63.55\end{array}$ & $\begin{array}{l}-39.23 \\
-79.79\end{array}$ & $\begin{array}{l}-399.15 \\
-340.08\end{array}$ \\
\hline 08/07/92 PH CONTROL NOT WORKING RIGHT** & 83.29 & 107.10 & 112.57 & 48.26 & 39.26 & -32.58 & -41.04 & -138.17 \\
\hline 08/11/92 PH UP TO 7.9 YESTERDAY CONTROLLER PROBLEM & 72.89 & 72.89 & 84.50 & 43.29 & 18.74 & ERR & ERR & \\
\hline 08/12/92 A.M. NO PH CONTROL & 67.07 & 60.65 & 65.29 & 18.61 & 14.11 & -16.08 & -12.89 & -40.06 \\
\hline P.M. NO PH CONTROL** & 76.43 & 70.45 & 60.45 & 19.36 & 12.01 & -10.48 & 4.11 & -8.72 \\
\hline 08/13/92 P.M. NO PH CONTROL** & 60.85 & 57.11 & 56.01 & 18.71 & 13.85 & -14.76 & -14.85 & -42.96 \\
\hline 08/14/92 A.M.NO PH CONTROL-** & 55.28 & 37.82 & 43.77 & $?$ & 5.69 & $?$ & -27.83 & 5.30 \\
\hline 08/20/92 A.M.I\&C PID PH CONTROLLER INSTALLED & 54.00 & 38.97 & 61.09 & 9.72 & 8.52 & 26.59 & -58.41 & -19.54 \\
\hline 08/20/92 P.M.PH CONTROL WORKS GOOD & 53.62 & 28.30 & 30.43 & 15.00 & 6.08 & -17.99 & -9.82 & -30.86 \\
\hline 08/21/92 SAND FILTER LEAK(POSSIBLE LOST GAS COLA)** & 48.22 & 37.20 & 34.85 & 21.60 & 7.27 & 10.34 & -14.60 & -2.98 \\
\hline 08/24/92 A.M. LEAK FIXED & 46.54 & 27.83 & 28.90 & 8.98 & 3.30 & 17.01 & -4.76 & 17.71 \\
\hline 08/24/92 & 45.94 & 24.96 & 24.39 & 18.26 & 3.60 & 10.07 & 1.22 & 12.90 \\
\hline $08 / 25 / 92$ & 48.38 & 25.40 & 25.85 & 14.36 & 1.26 & 8.98 & -3.51 & 8.27 \\
\hline $08 / 26 / 92$ & 46.30 & 19.16 & 19.15 & 4.31 & 9.56 & 37.02 & -9.15 & 42.57 \\
\hline $08 / 26 / 92$ & 42.27 & 15.00 & 22.26 & 15.86 & 7.33 & 30.21 & -79.33 & -7.74 \\
\hline $08 / 27 / 92$ & 45.41 & 10.41 & 10.38 & 6.00 & 4.58 & 57.19 & -26.13 & 56.35 \\
\hline $08 / 28 / 92$ & 50.93 & 8.41 & 50.46 & 4.18 & 2.71 & 81.16 & -518.94 & -8.20 \\
\hline $08 / 31 / 92$ & 42.91 & 4.37 & 1.28 & 2.77 & 2.54 & 78.08 & 42.37 & 87.66 \\
\hline $09 / 01 / 92$ & 39.33 & 3.99 & 5.04 & 2.26 & 2.03 & 70.03 & -55.35 & 67.78 \\
\hline
\end{tabular}




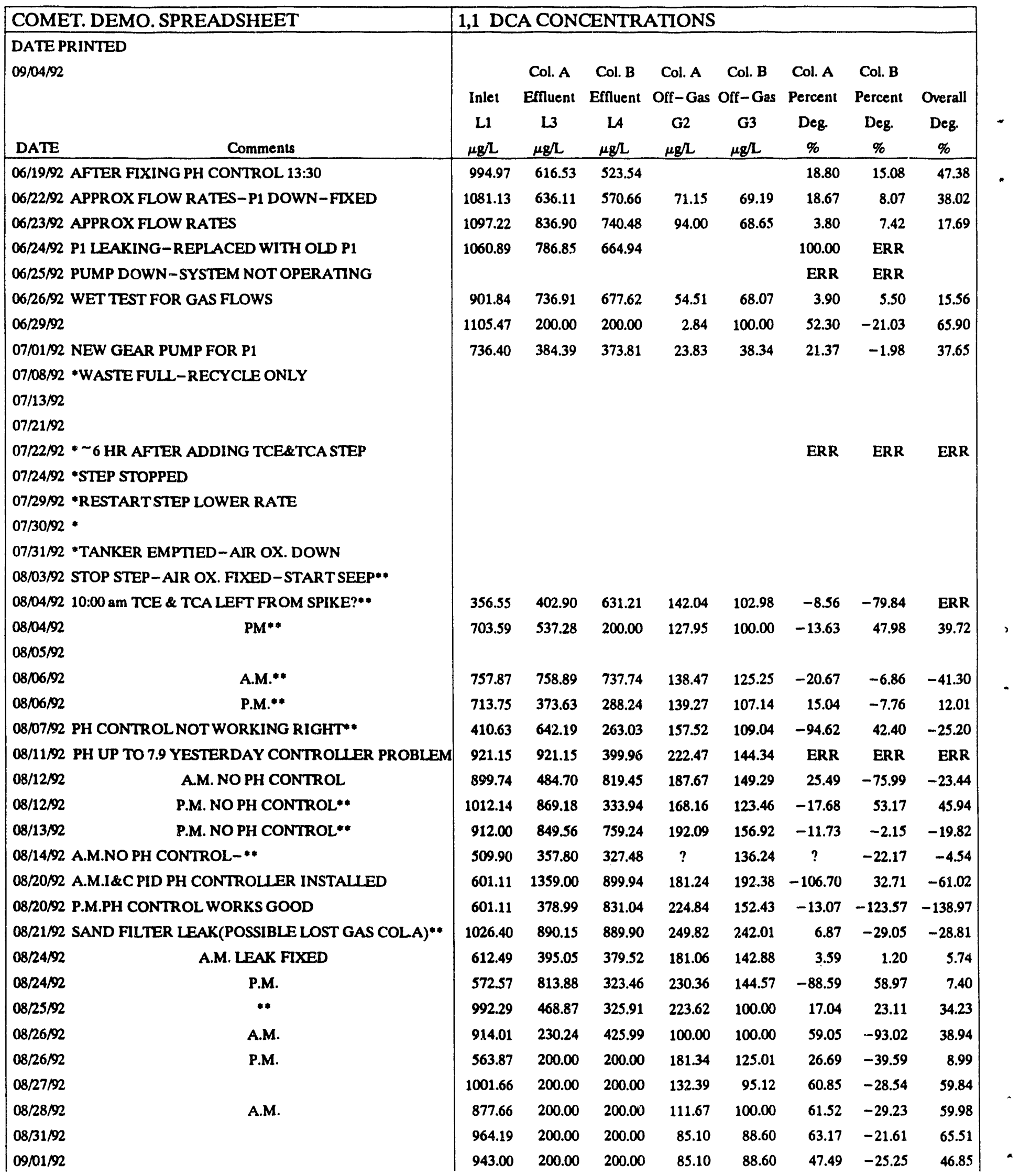




\begin{tabular}{|c|c|c|c|c|c|c|c|c|}
\hline COMET. DEMO. SPREADSHEET & \multicolumn{8}{|c|}{$1,1,1 \mathrm{TCA}$} \\
\hline $\begin{array}{l}\text { DATE PRINTED } \\
09 / 04 / 92\end{array}$ & $\begin{array}{c}\text { Inlet } \\
\mathrm{L} 1 \\
\mu \mathrm{g} / \mathrm{L}\end{array}$ & $\begin{array}{l}\text { Col. A } \\
\text { Effluent } \\
123 \\
\mu g / L\end{array}$ & $\begin{array}{c}\text { Col. B } \\
\text { Efnuent } \\
\text { LA } \\
\mu \mathrm{g} / \mathrm{L}\end{array}$ & $\begin{array}{l}\text { Col. A } \\
\text { Off-Gas } \\
\text { G2 } \\
\mu g / L\end{array}$ & $\begin{array}{l}\text { Col. B } \\
\text { Off-Gas } \\
\text { G3 } \\
\mu g / L\end{array}$ & $\begin{array}{l}\text { Col. A } \\
\text { Percent } \\
\text { Deg. } \\
\%\end{array}$ & $\begin{array}{l}\text { Col. B } \\
\text { Percent } \\
\text { Deg. } \\
\%\end{array}$ & $\begin{array}{l}\text { Overall } \\
\text { Deg. } \\
\%\end{array}$ \\
\hline 06/19/92 AFTER FIXING PH CONTROL 13:30 & 1912.83 & 593.09 & 397.44 & & & 48.66 & 32.99 & 79.22 \\
\hline 06/22/92 APPROX FLOW RATES-P1 DOWN-FDXED & 2020.27 & 622.30 & 438.33 & 359.75 & 300.23 & 34.75 & 19.70 & 54.42 \\
\hline 06/23/92 APPROX FLOW RATES & 1920.24 & 952.38 & 726.82 & 555.41 & 395.56 & 7.06 & 2.92 & 12.63 \\
\hline 06/24/92 P1 LEAKING-REPLACED WITH OLD P1 & 1921.81 & 877.65 & 578.49 & & & 100.00 & ERR & \\
\hline 06/25/92 PUMP DOWN-SYSTEM NOT OPERATING & & & & & & ERR & ERR & \\
\hline 06/26/92 WET TEST FOR GAS FLOWS & 1208.09 & 794.05 & 637.92 & 365.25 & 331.43 & -2.46 & 8.16 & 6.83 \\
\hline $06 / 29 / 92$ & 1748.34 & 148.43 & 47.55 & 53.36 & 0.75 & 62.64 & 67.76 & 91.34 \\
\hline $\begin{array}{l}\text { 07/01/92 NEW GEAR PUMP FOR P1 } \\
\text { 07/08/92 "WASTE FULL-RECYCLE ONLY } \\
07 / 13 / 92 \\
07 / 21 / 92\end{array}$ & 783.18 & 313.11 & 238.45 & 207.31 & 97.86 & 2.78 & 9.02 & 14.24 \\
\hline $\begin{array}{l}\text { 07/22/92 * } 6 \text { HR AFTER ADDING TCE\&TCA STEP } \\
\text { 07/24/92 *STEP STOPPED } \\
07 / 29 / 92 \text { *RESTART STEP LOWER RATE } \\
07 / 30 / 92 \text { * } \\
07 / 31 / 92 \text { *TANKER EMPTIED-AIR OX. DOWN } \\
08 / 03 / 92 \text { STOP STEP-AIR OX. FIXED-START SEEP** }\end{array}$ & 307.37 & 169.68 & 80.02 & 90.89 & 10.77 & -437.71 & 49.80 & ERR \\
\hline 08/04/92 10:00 am TCE \& TCA LEFT FROM SPIKE?** & 1550.91 & 1494.62 & 1302.89 & 398.41 & 364.92 & -18.09 & -9.30 & ERR \\
\hline $\begin{array}{l}08 / 04 / 92 \\
08 / 05 / 92\end{array} \quad P^{* *}$ & 1318.86 & 937.78 & 352.15 & 357.98 & 85.38 & -13.93 & 55.21 & 43.44 \\
\hline 08/06/92 & 1671.86 & 1525.03 & 1268.36 & 409.70 & 355.19 & -27.72 & 3.22 & -34.01 \\
\hline 08/06/92 P.M.** & 1388.49 & 1175.72 & 1035.79 & 418.11 & 330.91 & -18.80 & -18.14 & -49.15 \\
\hline 08/07/92 PH CONTROL NOT WORKING RIGHT** & 1816.90 & 1380.44 & 1126.98 & 414.23 & 255.28 & 2.97 & 0.24 & 4.26 \\
\hline 08/11/92 PH UP TO 7.9 YESTERDAY CONTROLLER PROBLEM & 1695.62 & 1150.37 & 1180.45 & 596.98 & 362.34 & ERR & ERR & ERR \\
\hline 08/12/92 A.M. NO PH CONTROL & 1722.92 & 1179.72 & 991.09 & 541.81 & 347.93 & -11.15 & 9.36 & -4.75 \\
\hline P.M. NO PH CONTROL** & 1969.31 & 1305.33 & 957.40 & 555.71 & 299.93 & 6.37 & 13.05 & 20.32 \\
\hline 08/13/92 P.M. NO PH CONTROL** & 1610.15 & 1113.09 & 885.74 & 537.72 & 307.91 & -4.50 & 1.29 & -4.43 \\
\hline 08/14/92 A.M.NO PH CONTROL-** & 1560.90 & 846.86 & 612.30 & & 198.90 & $?$ & 8.80 & 41.55 \\
\hline 08/20/92 A.M.I\&C PID PH CONTROLLER INSTALLED & 1838.00 & 1297.00 & 1541.15 & 141.16 & 111.60 & 24.88 & -19.48 & 13.48 \\
\hline 08/20/92 P.M.PH CONTROL WORKS GOOD & 1838.00 & 895.73 & 899.00 & 185.89 & 98.89 & 20.26 & -1.54 & 24.09 \\
\hline 08/21/92 SAND FILTER LEAK(POSSIBLE LOST GAS COLA)** & 1747.80 & 1202.77 & 1028.62 & 351.53 & 242.01 & 17.53 & -7.04 & 15.67 \\
\hline 08/24/92 $\quad$ A.M. LEAK FIXED & 1716.98 & 963.17 & 815.89 & 292.25 & 218.03 & 18.76 & 13.58 & 33.96 \\
\hline $08 / 24 / 92$ & 1668.24 & 799.31 & 699.97 & 343.16 & 179.19 & 28.45 & 10.81 & 39.79 \\
\hline $08 / 25 / 92$ & 1765.94 & 876.22 & 713.70 & 132.00 & 0.19 & 32.57 & 18.54 & 50.25 \\
\hline $08 / 26 / 92$ & 1782.08 & 524.17 & 425.99 & 142.69 & 19.64 & 48.78 & 18.04 & 67.82 \\
\hline $08 / 26 / 92$ & 1685.07 & 436.94 & 377.74 & 26.79 & 11.98 & 59.15 & 11.81 & 75.28 \\
\hline $08 / 27 / 92$ & 1854.58 & 425.41 & 284.57 & 81.86 & 54.00 & 61.25 & 25.49 & 78.18 \\
\hline $08 / 28 / 92$ & 1722.61 & 418.61 & 277.14 & 173.80 & 27.70 & 58.71 & 29.93 & 77.61 \\
\hline $08 / 31 / 92$ & 1751.99 & 383.75 & 261.06 & 98.16 & 6.87 & 61.65 & 31.10 & 81.13 \\
\hline $09 / 01 / 92$ & 1678.94 & 90.81 & 64.31 & 1.11 & 0.79 & 89.43 & 28.69 & 95.96 \\
\hline
\end{tabular}




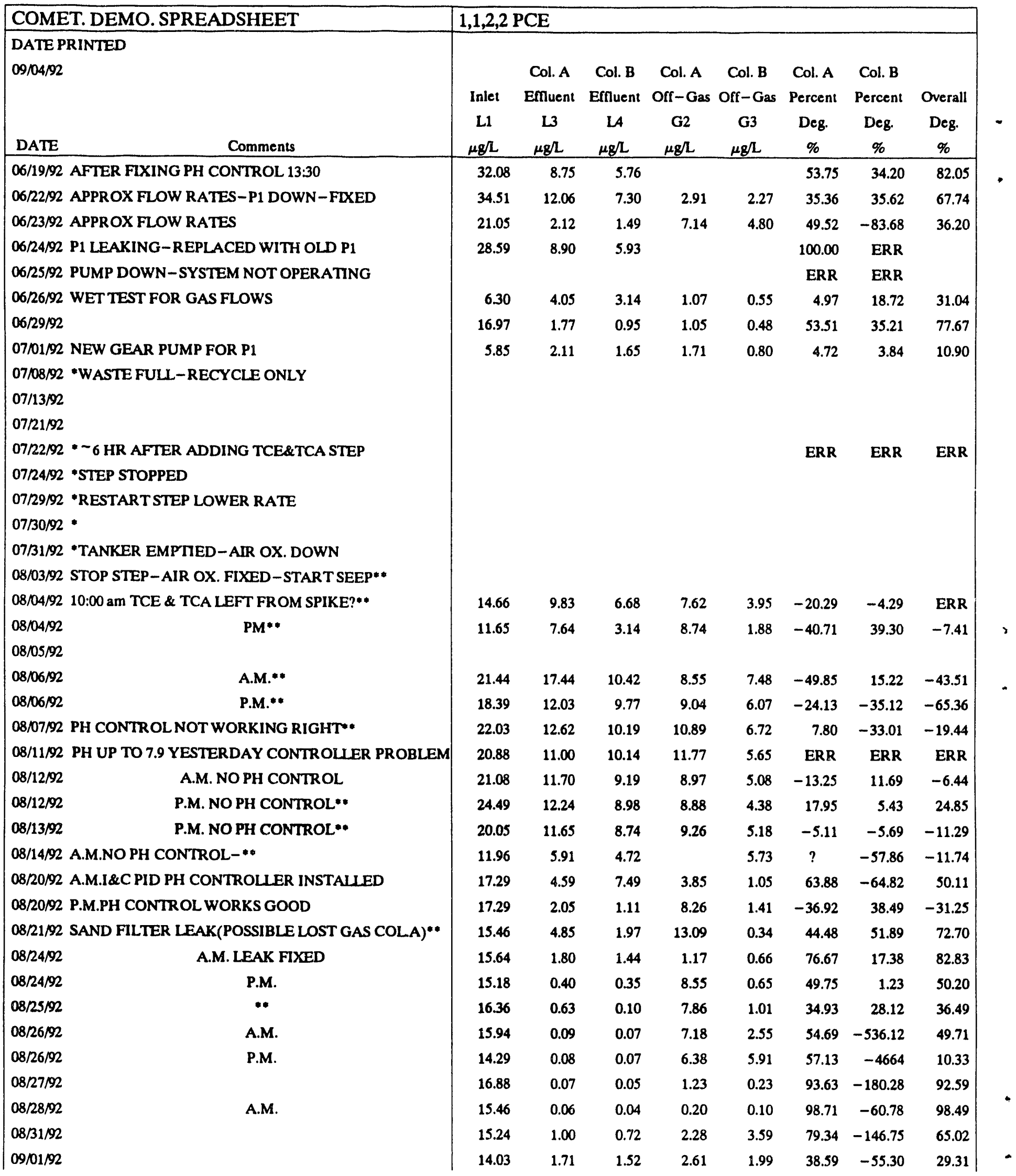

* System operated in total recycle with no seep water feed while awaiting effluent disposal.

** Off-gas flow rate from Column $B$ may be too high due to problems with the flow measurement procedures. 
ORNL/TM-12235

\section{INTERNAL DISTRIBUTION}

1. C. H. Brown, Jr.

2. A. G. Croff

3. B. H. Davison

4-8. T. L. Donaldson

9. C. W. Gehrs

10. R. K. Genung

11-15. S. E. Herbes

16-20. H. L. Jennings

21. R. L. Jolley

22. K. S. Jones

23. K. T. Klasson

24-28. A. J. Lucero

29. R. Machanoff

30. A. P. Malinauskas

31. C. P. McGinnis

32. C. M. Morrissey

33. A. V. Palumbo

34. T. J. Phelps
35. J. G. Pruett

36. M. E. Reeves

37. S. M. Robinson

38. M. K. Savage

39. T. C. Scott

40. R. L. Siegrist

41. S. H. Stow

42. G. W. Strandberg

43. R. L. Tyndall

44. R. I. Van Hook

45. A. B. Walker

46. J. F. Walker, Jr.

47. Central Research Library

48. Document Reference Section

49. Laboratory Records - RC

50-51. Laboratory Records

52. ORNL Patent Section

\section{EXTERNAL DISTRIBUTION}

53. P. R. Bienkowski, The Chemical Engineering Department, The University of Tennessee, 419 Dougherty, Knoxville, Tennessee 37996-2200.

54. T. C. Hazen, Westinghouse Savannah River Company, Building 773-42A, P.O. Box 616, Aiken, South Carolina 29805.

55. J. O. Moore, Department of Energy, Oak Ridge Operations, Post Office Box 2001, Oak Ridge, Tennessee 37831-2116.

56. G. D. Reed, Civil Engineering Department, The University of Tennessee, 223 Perkins Hall, Knoxville, Tennessee 37996-2010.

57. G. S. Sayler, Center for Environmental Biotechnology, 10515 Research Drive, Suite 200, Building 1, Knoxville, Tennessee 37932

58. Office of Assistant Manager, Energy Research and Development, Department of Energy, Oak Ridge Operations,P. O. Box 2001, Oak Ridge, TN 37831.

59-68. Office of Scientific and Technical Information, P. O. Box 60, Oak Ridge, Tennessee 37831. 

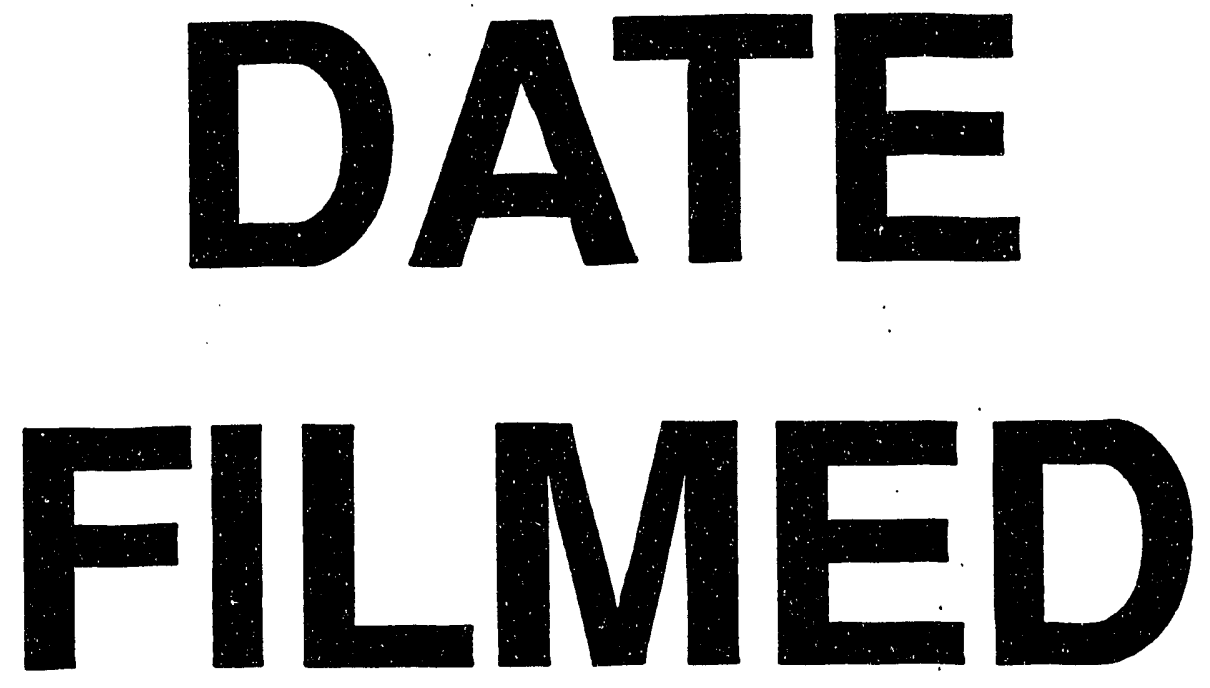

$9 / 27 / 93$
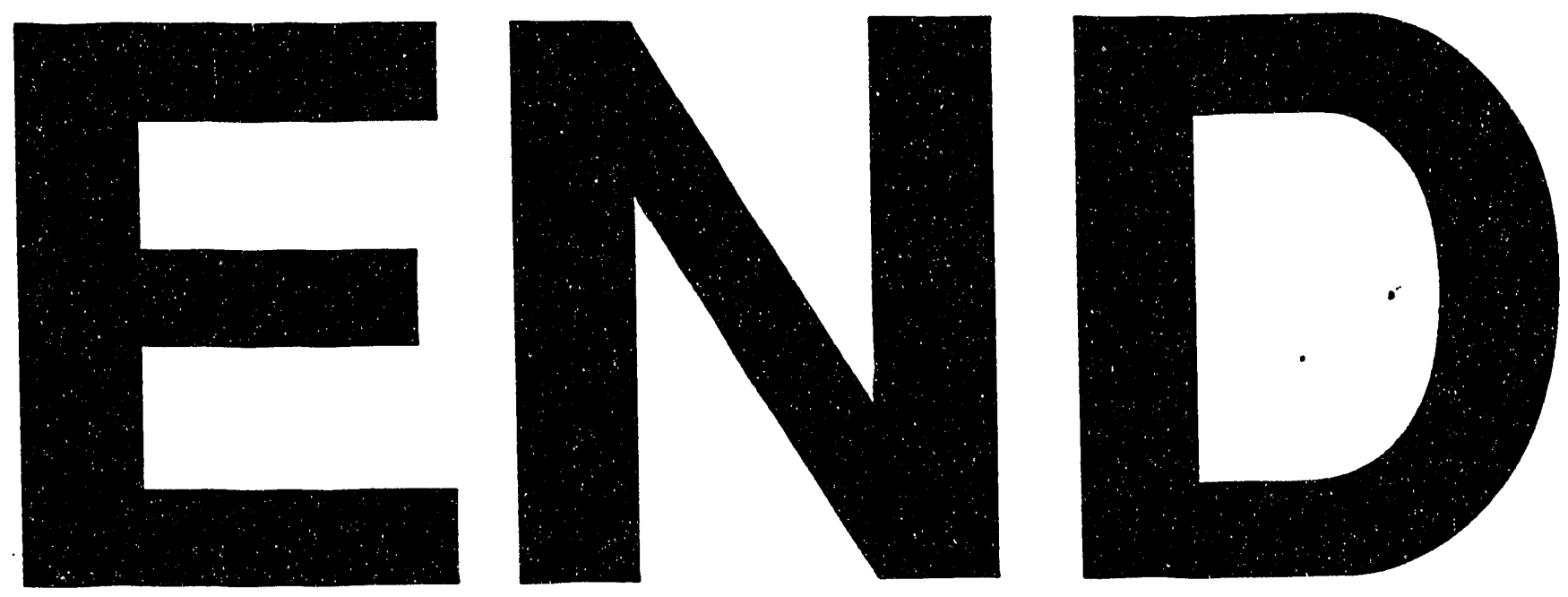
- 